serie Opinion-shopping:

\title{
Partner versus firm-level evidence
}

WP-EC 2016-02 Beatriz García, Belén Gill-de-Albornoz and Elena de las Heras

\section{Ivie}

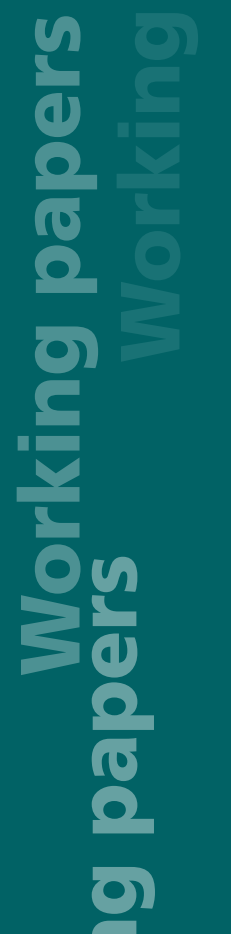


Los documentos de trabajo del Ivie ofrecen un avance de los resultados de las investigaciones económicas en curso, con objeto de generar un proceso de discusión previo a su remisión a las revistas científicas. Al publicar este documento de trabajo, el Ivie no asume responsabilidad sobre su contenido.

Ivie working papers offer in advance the results of economic research under way in order to encourage a discussion process before sending them to scientific journals for their final publication. Ivie's decision to publish this working paper does not imply any responsibility for its content.

La Serie EC, coordinada por Matilde Mas, está orientada a la aplicación de distintos instrumentos de análisis al estudio de problemas económicos concretos.

Coordinated by Matilde Mas, the EC Series mainly includes applications of different analytical tools to the study of specific economic problems.

Todos los documentos de trabajo están disponibles de forma gratuita en la web del Ivie http://www.ivie.es, así como las instrucciones para los autores que desean publicar en nuestras series.

Working papers can be downloaded free of charge from the Ivie website http://www.ivie.es, as well as the instructions for authors who are interested in publishing in our series.

Versión: mayo 2016 / Version: May 2016

Edita / Published by:

Instituto Valenciano de Investigaciones Económicas, S.A.

C/ Guardia Civil, 22 esc. $21^{\circ}-46020$ Valencia (Spain)

DOI: http://dx.medra.org/10.12842/WPASEC-2016-02 
WP-EC 2016-02

\title{
Opinion-shopping: Partner versus firm-level evidence*
}

\author{
Beatriz García Osma, Belén Gill-de-Albornoz Noguer and \\ Elena de las Heras Cristóbal ${ }^{* *}$
}

\begin{abstract}
We study the strategies, timing and relative outcomes obtained by companies that attempt to shop for more favorable audit opinions both at the firm and at the partner level. Using a uniquely long time series of Spanish firms' data, we employ the Lennox's (2000) methodology and find evidence of successful opinion-shopping through voluntary firm switching. In contrast, our results suggest that voluntary audit partner switches are associated with a fresh eye effect. Additionally, we document that firm switching activity is more likely when prior attempts to shop for an opinion were unsuccessful. Finally, we show that the fresh eyes effect associated with partner switching disappears when partner rotation becomes mandatory; and that under such a regulatory setting firm-level opinion-shopping is still pervasive.
\end{abstract}

Keywords: opinion-shopping, auditor switches, modified audit reports, mandatory partner rotation.

JEL Classification: M42, M48.

\section{Resumen}

Estudiamos las estrategias empresariales para conseguir informes de auditoria con opiniones mas favorables, tanto a nivel de firma como de socio. Utilizando la metodología de Lennox (2000) y la comparación entre la opinión pre y post cambio de auditor, proporcionamos evidencia de la existencia de compra de opinión a través del cambio voluntario de firma de auditoría. Sin embargo, los resultados sugieren que los cambios voluntarios del socio de auditoría están asociados con un efecto "ojos frescos". Además, los cambios de firma son más probables cuando previamente se han producido intentos de compra de opinión que no han tenido éxito. Finalmente, se proporciona evidencia de que el efecto "ojos frescos" asociado a los cambios voluntarios de socio desaparece cuando la rotación del socio es obligatoria; y que la compra de opinión a nivel de firma sigue existiendo en un contexto de rotación obligatoria del socio.

Palabras clave: compra de opinión; cambio de auditor; opinión con salvedades; rotación obligatoria del socio.

Clasificación JEL: M42, M48.

\footnotetext{
* This paper has benefited from comments by Patrick Krauß, seminar participants at University Autónoma de Madrid, University of Navarra, University of Murcia, Zurich University, the VIII Workshop on Empirical Research in Financial Accounting, the 2012 Annual Meeting of the American Accounting Association, and the XXIII Finance Forum. We acknowledge financial contribution from AECA, Spanish Ministry of Science and Innovation (ECO2013-48328), Cátedra UAM-ICJCE/AT1, and Universidad Jaime I through the research project funding (09I340 P11B2009-05). We are grateful to the CNMV (Spanish Stock Exchange Commission) for the award to the best paper on regulation presented in the XXIII Finance Forum (Madrid, Spain).

** B. García Osma: Universidad Carlos III de Madrid, B. Gill-de-Albornoz Noguer: Universitat Jaume I \& Ivie, E. de las Heras Cristóbal: Universidad Autónoma de Madrid.

Corresponding author: Belén Gill-de-Albornoz, E-mail: noguer@cofin.uji.es.
} 


\section{INTRODUCTION}

According to Lennox (2003), opinion-shopping occurs whenever an audit client dismisses (or retains) its incumbent audit firm with the intention of obtaining a more favorable audit opinion. For decades, regulators have expressed concerns about this phenomenon (e.g., EC 2010; SEC 1988; U.S. Senate 1976), on which academic evidence is limited (DeFond and Zang 2014: 310). Recently, the Public Company Accounting Oversight Board (PCAOB) warned that opinionshopping may happen also at the partner level, since companies could inappropriately pressure their audit firms to substitute the engagement partner with a more lenient one (PCAOB 2011; 2013). ${ }^{1}$ The work of Chen, Peng, Xue, Yang and Ye (2016), studying the case of China, provides the first evidence of opinion-shopping at the partner level, and sets the question of what strategies firms engage in to secure more agreeable auditors. We contribute to this literature by studying opinion-shopping both at the firm and partner levels. This permits a more complete analysis of the strategies, timing and relative outcomes obtained by companies that attempt to shop for more favorable audit opinions.

Our study responds to the calls for further research on the contrasting firm versus partner effects of auditing (e.g., Bamber and Bamber 2009; DeFond and Zhang 2014). We argue that there are three salient elements associated with opinion-shopping that make it a particularly interesting context to explore such differential effects. The first one relates to visibility. Attempts to opinion shop at the partner level likely benefit from lower visibility. Many jurisdictions require companies and/or auditors to inform about firm switches and the reasons that motivate

\footnotetext{
${ }^{1}$ Hereafter, we use the terms company and firm to refer respectively to the audit client and the audit firm.
} 
them, while partner switches remain opaque. ${ }^{2}$ Even when the incumbent partner identity is public, partner switches do not garner as much attention from the market participants as firm switches. $^{3}$

The second element relates to the relative costs of the switch. Auditor switches benefit the company similarly at either level if they result in a more favorable opinion. However, switches are not without costs, and these are potentially higher when the switch occurs at the firm level because the auditor's client-specific knowledge that is key to conduct the audit is lost in the switch, while the learning curve about the client's operations is less steep when only the partner changes (AICPA 1978, 1992; Bamber and Bamber 2009; GAO 2004).

The third element refers to the audit market structure. Successful opinion-shopping hinges crucially on companies finding a more lenient auditor, which can happen when, ceteris paribus incentives, there is sufficient heterogeneity in audit quality. Thus, the pervasiveness of opinion-shopping depends on the market characteristics that determine the degree of heterogeneity in audit quality, and these might differ at the firm and partner levels. At the firm level, the literature suggests that the probability of finding a more lenient auditor increases in settings with weak investor protection and inefficient enforcement (DeFond, Wong and Li 2000; Chan, Lin and Mo 2006), as well as in competitive audit markets (Newton, Persellin, Wang and Wilkins 2016). At the partner level, the existence of heterogeneity in quality additionally

\footnotetext{
${ }^{2}$ For example, in the U.S. the SEC Regulation S-K 304 requires registrants to provide specific disclosures whenever there is an auditor change. Similar requirements are established by Spanish auditing standards.

${ }^{3}$ As an example, on December 4th 2015 the Spanish newspapers reported the announcement of Telefónica, one of the largest telecom companies in the world, that they would rotate their audit firm, Ernst \& Young (EY), in 2017 to comply with the recent European Union (EU) mandatory rotation policy that requires firm rotation after 10 years. The company invited bids by PriceWaterhouse Coopers (PwC), Deloitte \& Touche (DT) and KPMG (e.g., Navas 2015). However, our records indicate that Telefónica changed its EY's partner in 2010, and we are not aware that any public announcement was made by the company at that time, or that the media paid attention to that switch.
} 
depends on firm-specific factors, like the quality of internal control mechanisms and legal form. So far, opinion-shopping at the partner level has been studied only in China, where the internal control mechanisms of firms are weak; therefore, competitiveness among audit partners is high, and achieving consistent audit quality across partners of the same firm is difficult (Chen et al. 2016).

In this paper, we exploit the Spanish setting, where partner identity is public since mandatory audits were established by the Audit Law of 1988. This provides us with a uniquely long time-series of data on auditor switching, both at the firm and partner levels. Spain is the fourth largest economy of the Eurozone (CIA 2014). Similar to other continental European countries, it has a weak public oversight system for statutory audits (García Osma, Gisbert and Heras 2016), overall weak institutions (La Porta et al. 2000), and has not experienced substantive changes to its enforcement mechanisms in the last decades (Christensen, Hail and Leuz 2013). Moreover, despite a high concentration of the listed companies audit market, the competition amongst audit firms is high. These characteristics are similar to the Chinese setting, and encourage opinion-shopping at the firm level. However, the audit market at the partner level is different. The market for competent partners is thin and concentrated. Additionally, audit firms are based on the partnership model of ownership that promotes monitoring among partners.

The specificities of our setting, together with the above discussion on the contrasting effects of the switching decision at the firm versus the partner levels, lead us to formulate two main predictions. First, we expect a higher incidence of opinion-shopping at the firm level. The market features at the firm and partner levels suggest that heterogeneous audit quality among partners of the same audit firm (within-firm heterogeneity) should be lower than among partners of different firms (across-firm heterogeneity), which implies less possibilities for successful 
opinion-shopping at the partner level. Second, we predict a pecking order in the switching preferences of audit clients. In particular, we argue that partner-level opinion-shopping is preferred, and that the firm switching activity is associated with prior opinion-shopping attempts that were unsuccessful to secure the desired opinion.

We employ the Lennox (2000) methodology to determine whether companies successfully engage in firm-level and/or partner-level opinion-shopping. The results are consistent with successful opinion-shopping at the firm level, but not at the partner level. These findings are confirmed when we compare pre and post-switch audit opinions: voluntary firm switching positively relates with the probability of opinion upgrading (i.e., getting a clean report after a modified one), while the relation between voluntary partner switches and the probability of opinion upgrading is significantly negative. These results confirm the opinion-shopping behavior at the firm level and suggest that voluntary partner switching relates to a fresh eye effect, which contrasts with the findings of Chen et al. (2016). Regarding our second prediction, our results suggest the implementation of increasingly aggressive opinion-shopping attempts. Specifically, we find that the probability of firm switching is significantly higher when prior partner-level or firm-level switching decisions fail to secure the desired opinion.

An additionally interesting element of our setting is that Spain has had a number of audit regulatory changes in the last decades, which permits examining the impact of regulation on opinion-shopping. In particular, the Financial Law of 2002 imposed mandatory partner rotation and limited the responsibility of partners within the same firm. We argue that these regulatory changes favored opinion-shopping opportunities at the partner level. Results support this prediction since the fresh eye effect associated with voluntary partner switching disappears when partner rotation becomes mandatory. Moreover, despite the higher opportunities to opinion-shop 
at the partner level, we observe that the opinion-shopping activity at the firm level is still pervasive after 2002 .

Our findings contribute to the prior literature in a number of ways. First, we add to the international evidence on opinion-shopping behavior. As stated by DeFond and Zang (2014), one limitation of the opinion-shopping research is the reduced number of studies carried on so far. Providing evidence in different settings is necessary for a better understanding of the audit market characteristics that promote or deter the opinion-shopping activity. Second, we respond to the calls for additional evidence on the differential effects of audit firm and partner characteristics on audit quality. This is the first study that analyzes opinion-shopping at both firm and partner levels. We find that the voluntary auditor switching decision has different effects on audit quality at the firm and the partner levels. We show that opinion-shopping is a problem at the firm level but not at the partner level in the setting analyzed, which contrasts with the evidence found in China by Chen et al. (2016) and suggests that the audit market structure is fundamental in explaining heterogeneous audit quality at both the firm and the partner level. Additionally, analyzing both firm and partner levels permits providing novel evidence on the companies' strategies to secure more favorable audit opinions. Our results suggest that companies prefer switching partners than firms, and that they use an escalation in strategies. Finally, our evidence questions the efficacy of mandatory partner rotation regulation, particularly in thin markets, since the fresh eyes effect associated to voluntary partner switching disappears when partner rotation becomes mandatory. 


\section{THE AUDIT INSTITUTIONAL SETTING IN SPAIN}

We predict that the market features crucially determine opinion-shopping behavior. Thus, in this section, we describe the main characteristics of the Spanish audit framework. Appendix I provides additional detailed evidence of the setting under analysis.

The greatest change to the Spanish audit profession occurred after the country joined the EU in 1986. The enactment of the first Audit Law (Law 19/1988) was a response to the EU Company Law Directives, which establish mandatory audits for medium- and large-sized companies (Garcia-Benau, Ruiz-Barbadillo, Humphrey and Husaini 1999). Thereafter, the development of the audit regulation runs parallel to that of the EU.

\section{Appointment of External Auditors and Auditor Rotation}

The Companies Law establishes that shareholders are responsible for appointing the external auditor. In practice, managers effectively control the appointment process, similar to other countries (e.g., Dhaliwal, Lamoreaux, Lennox and Mauler 2015). Once appointed, the auditor can be dismissed before the end of the contract period if there is a 'fair' cause. In addition, the Audit Law of 1988 imposed mandatory firm rotation every nine years (article 8.4). Since then, the profession has witnessed several changes regarding auditor rotation requirements, which we represent chronologically in Figure 1. In 1995, even before it could be enforced, the firm mandatory rotation rule was dropped by the Limited Responsibility Companies Law (Law 2/1995). As a consequence, auditor rotation was de facto unregulated until the enactment of the Financial Law in 2002 (Law 44/2002). This law established a partner-level mandatory rotation rule: large companies must rotate the key audit partners and the responsible team within a maximum period of seven years from the date of appointment (article 51). The Audit Law of 
2010 (Law 12/2010) slightly changed the details of this rule by requiring only the partner, and not the team, to rotate every seven years. Finally, the current Audit Law, enacted in July 2015 (Law 22/2015), requires again mandatory rotation of the firm (every ten years) ${ }^{4}$ while keeping the rule of mandatory partner rotation (now every five years).

\section{Figure 1: Auditor rotation requirements in Spain.}

The figure illustrates the main regulatory regimes in Spain since auditing was first regulated in 1988 until the last regulatory change occurred in 2015. Our sample period covers two main regulatory periods: 1995-2002 where both firm and partner switches were all voluntary; and 2003-2014 where firm switches remain voluntary and partner changes could be either voluntary or mandatory.

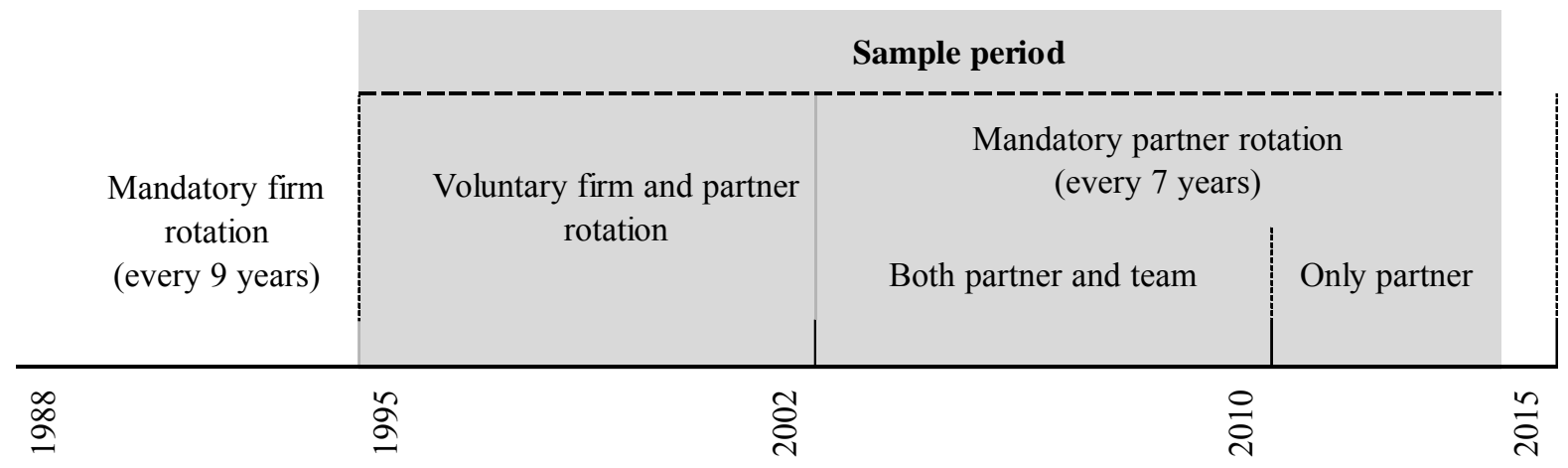

As we explain in detail in the subsequent sections, our sample covers the period 1995 2014. Therefore, it can be divided into two distinct regulatory periods: 1995 to 2002, where all auditor switches observed are voluntary; and 2003 to 2014, where firm switches remain voluntary while partner switches can be either voluntary or mandatory.

\section{Auditor Communication}

Auditors have to issue a clean opinion whenever the financial statements show the true and fair view of a firm's financial situation without any reservation. Otherwise, the opinion has to be

\footnotetext{
${ }^{4}$ This requirement will be effective from 2017 onwards and is imposed by the European Commission (EC) Regulation 537/2014 (EC 2014a), an output of the last European audit market reform, which began with the Green Paper 'Audit Policy: Lessons from the Crisis' (EC 2010). The other regulatory output that resulted from this reform is the Directive 2014/56/EC (EC 2014b), which modified the Directive 2006/43/EC (EC 2006).
} 
modified, and the reasons explained. There are four reasons to issue a modified report: (a) material errors or non-compliance are identified; (b) limitations in the scope of the audit work; (c) uncertainties; and (d) accounting policies applied that are inconsistent with those applied in the previous year. ${ }^{5}$ Additionally, the auditor could issue an adverse opinion if the financial statements do not reflect the true and fair view; or a disclaimer of opinion when she is unable to give an opinion due to lack of information. Notwithstanding this, adverse opinions and disclaimers of opinion are very infrequent, particularly among listed firms.

\section{Audit Market Structure}

Most listed companies are audited by one of the large multinational firms. Small and medium firms face high barriers to entry. According to the EC report by Le Vourc'h and Morand (2011) this occurs in most EU audit markets. ${ }^{6}$ Despite the high concentration, competition among the big firms is high, as indicated by (1) the high variation in their market shares (see Table A1 of Appendix I), and (2) the low audit fees. According to the Spanish Institute of Chartered Accountants, in 2014 the audit work was paid on average at a remarkably low price of 67 EUR per hour (ICJCE 2014). Indeed, Spain has one of the lowest audit fees over turnover ratios in the EU (LeVourch and Morand 2011: 147). The high competition among firms encourages them to differentiate their services and gives rise to heterogeneity in the quality across firms.

\footnotetext{
${ }^{5}$ None of these types of modified opinions map precisely with the going concern (GC) opinion as understood under U.S. standards. As pointed out by DeFond and Zhang (2014), modified opinions are typically used in the literature as an alternative to GC in jurisdictions outside the U.S. (e.g., Vanstraelen 2000; Chan and Wu 2011).

${ }^{6}$ Using data of 2009, Le Vourc'h and Morand (2011) report an average Hirschman-Herfindahl Index by turnover (HHI) of 2,709 for the EU. The HHI is 4,050 for Spain. As a rule, a HHI below 1,000 indicates low concentration; between 1,000 and 2,000 moderate concentration; and higher than 2,000 high concentration.
} 
Conversely, competition amongst partners within the same firm is low. The market for competent, expert partners is thin and concentrated in a reduced number of offices that are geographically close. ${ }^{7}$ There are only a few partners within the same firm with enough expertise to audit any given listed company, as many partners are usually specialized in a few industries (see Table A2 of Appendix I). Moreover, audit firms are organized using the partnership model of ownership, which encourages monitoring between partners (Levin and Tadelis, 2005). Therefore, the quality of the partners within each firm is expected to be homogeneous.

\section{RELATED LITERATURE AND HYPOTHESES}

Because of the expected negative consequences of modified reports (e.g., Bamber and Stratton 1997; Chen, He, Ma and Stice 2012; Choi and Jeter 1992; Firth 1980; Gul 1987; Kausar, Taffler and Tan 2009; Taffler, Lu and Kausar 2004), managers are predicted to pressure auditors to issue clean opinions; and, if that fails, they might switch the auditor in the hope that the new auditor is more willing to issue a clean report (e.g., Lennox 1998; Teoh 1992). This is commonly referred to as opinion-shopping behavior, which impairs auditor independence if the companies' pressure leads to more favorable opinions. Accordingly, regulators worldwide have recurrently discussed the need to implement measures that reduce the threat of auditors acquiescing to opinionshopping (e.g., EC 2010; PAOBC 2011, 2013; US Senate 1976).

\footnotetext{
${ }^{7}$ Deloitte and PwC have twenty offices, KPMG has sixteen and EY has fourteen. The mean (median) distance between each KPMG office is $165 \mathrm{~km} / 103$ miles $(250 \mathrm{~km} / 155$ miles); the mean (median) distance between each KPMG office and the central office in Madrid is $491 \mathrm{~km} / 305 \mathrm{miles}(578 \mathrm{~km} / 359$ miles). Similar distances apply to the other firms, as most of them have offices in the same cities (all Big 4 are present in the same twelve cities).
} 


\section{Prior research on opinion-shopping at the firm and the partner level}

There is evidence that modified opinions are associated with subsequent firm switches (e.g., Chow and Rice 1982; Citron and Taffler 1992; Craswell 1988; DeFond and Subramanyam 1998; Krishnan 1994; Krishnan and Stephens 1995; Smith 1986). One interpretation of this finding is that companies change auditors to avoid receiving modified reports (e.g., Dye 1991; Matsumura, Subramanyam and Tucker 1997). Consistent with this view, prior work shows that managers attempt to avoid modified reports by choosing local or small firms, since these are more likely to issue clean reports (e.g., Chan et al. 2006; Davidson, Jiraporn and DaDalt 2006; DeFond et al. 2000; Gomez-Aguilar and Ruiz Barbadillo 2003).

Although the association between modified opinions and subsequent auditor switches suggests that companies attempt to opinion shop, it does not necessarily mean that auditors actually acquiesce to it. Indeed, the evidence that companies get more favorable opinions after switching the audit firm is limited (e.g., Chow and Rice 1982; Smith 1986), and prior research has explored alternative explanations to the observed relation between modified opinions and subsequent firm switches. For example, Krishnan (1994), Krishnan and Stephens (1995) and DeFond and Subramanyam (1998) suggest that firm switches after receiving a modified report are explained by the conservatism of the incumbent auditor.

The work by Lennox (2000) represents a turning point in this stream of research. He questions the conclusion that opinion-shopping is futile as derived from the lack of evidence in studies analyzing pre- and post-switching opinions. Even though observed post-switch opinions are not more favorable than pre-switch opinions, his research indicates that U.K. companies successfully incur in opinion-shopping because their switching decisions minimize the probability of receiving modified reports. Subsequent studies have used his approach to analyze 
opinion-shopping at the firm level from different perspectives, and in different settings (e.g., Lennox 2003; Newton et al. 2016; Ruiz-Barbadillo, Gómez-Aguilar and Biedma-López 2006).

To the best of our knowledge, there is only one study on opinion-shopping at the partner level, namely Chen et al. (2016), who use the Lennox's methodology and show that companies successfully pressure audit firms into removing non-acquiescent partners in China. A number of specificities of the Chinese setting make the existence of opinion-shopping at the partner level especially likely. First, companies experience significant pressures to avoid modified reports, as these may weight in the delisting decisions of the stock market regulator. Second, the market of partners is dispersed, and firms have low quality control mechanisms, thereby increasing competition for clients among partners within the same firm. Finally, institutions in China are weak, and investor protection and litigation risk for auditors low. These features result in significant differences in quality across partners, as shown in Gul, Wu and Yang (2013).

In sum, the extant literature leads us to argue that opinion-shopping hinges critically on two conditions. The first one is that there is sufficient heterogeneity in audit quality, either across firms and/or across partners within the same firm. Faced with heterogeneous audit quality, companies are able to identify more lenient auditors. The second condition is that managers can influence the appointment of auditors, meaning that once a more lenient auditor has been identified, the existing institutions facilitate the switch of interest.

\section{Firm versus partner level opinion-shopping: Factors that determine the incentives of clients} and auditors

We argue that the evidence on opinion-shopping surrounding firm switching decisions cannot be extrapolated to the partner setting for at least three reasons. First, the visibility of the firm 
switching decision is greater than that of the partner switching decision. Some studies document that auditor switches have adverse capital market effects (e.g., Einchenseher, Hagigi and Shields 1989; Fried and Schiff 1981; Kim and Park 2006; Smith and Nichols 1982). Consequently, since partner switches are more opaque than firm switches, companies might prefer to shop for a more favorable opinion within the same firm, thus avoiding the unintended consequences of the switch while still receiving the benefits. An even more opaque and perhaps more likely attempt to opinion shop could happen when partners rotate because of internal firm procedures, partner retirement, illness, etc. In those cases, managers who may not have actively sought the change of the partner can influence the outcome of the forced switch, effectively using it to find a more lenient partner. The lack of visibility is also obvious when managers opinion-shop by not switching auditors. Retention decisions are entirely opaque at the partner level. For example, partner retention is not discussed in the Annual General Meeting, while firm retention decisions must be a point in the agenda.

A second consideration relates to the net costs associated with each type of switch. Literature suggests that the net costs of switching the partner are lower than those associated with a firm switch. The salient cost associated with an auditor switch is that the client-specific knowledge generated with the auditor's tenure is lost (Beck and Wu 2006). ${ }^{8}$ As stated in Bamber and Bamber (2009), a significant part of this client-specific knowledge resides on the audit team, the audit procedures, the audit methodology and the working papers created in prior engagements, all of which are usually available to the partners of the same firm. When the firm switches, the costs of creating the intangible resources associated with the auditor's tenure are

\footnotetext{
${ }^{8}$ Indeed, most prior literature links longer audit tenures with higher competence (e.g., Johnson, Khurana and Reynolds 2002; Myers, Myers and Omer 2003).
} 
split between the client and the firm, meaning that it is more costly to switch firms than partners not only for the auditor but also for the client.

The arguments above lead us to predict that, ceteris paribus, companies prefer to opinionshop at the partner level, as partner-level opinion-shopping benefits from being more opaque and less costly. However, as previously argued, only if sufficient differences in quality exist (in terms of competence, and mainly of independence), companies could find more lenient auditors and succeed in their attempts to get more favorable opinions. This explains that firm-level opinionshopping is more common in settings characterized by low investor protection and weak enforcement mechanisms. These institutional characteristics should also foster partner-level opinion-shopping, but they are not sufficient because the level of heterogeneity in audit quality critically depends on key features of the market, such as concentration and competitiveness, that are not necessarily identical in the markets of firms and partners. This is the third aspect that we argue may underlie a different opinion-shopping behavior at the firm and the partner levels.

Chen et al. (2016) suggest that partner-level opinion-shopping occurs in China because of two main characteristics of the market: first the market is dispersed, thereby increasing competition for clients among firms, but also, among partners of the same firm, since the offices of the same firm are far from each other; and second, the internal control mechanisms of audit firms are weak, and thus, partners of the same firm have low incentives to monitor one another. In fact, Chen et al. (2016) show that the pervasiveness of partner-level opinion-shopping is higher when firms are organized as corporations than when they adopt the partnership ownership form.

The Spanish setting under analysis shares some characteristics with China, like the weak enforcement mechanisms and public oversight system for statutory audits (Christensen et al. 
2013; García Osma et al. 2016). However, as opposed to China, the structure of the Spanish market differs at the firm and the partner levels. The market for audit firms is concentrated but highly competitive (Ruiz Barbadillo, Rodriguez Castro and Biedma López 2016), while the market for competent, expert partners is thin, and concentrated in a reduced number of geographically close offices. Additionally, the partnership model of the audit business promotes monitoring among partners. This should prevent partners from acquiescing to opinion-shopping within their own firm.

\section{Hypotheses}

Considering the previous discussion, we expect that opinion-shopping will be more prevalent at the firm level than at the partner level. We therefore formulate two hypotheses:

H1a: Companies successfully engage in firm-level opinion-shopping.

H1b: Companies successfully engage in partner-level opinion-shopping.

We also argue that partner-level opinion-shopping is preferred by clients, given its lower visibility and net costs. To the extent that managers can equally influence the change of the partner or of the firm, it is likely that they prefer to change the partner, and if that fails, then, change the firm. Our argument implies a certain strategy and timing; we expect that companies' attempts to opinion shop at the partner level likely precede firm-level opinion-shopping attempts. Therefore, we formulate the following hypothesis:

\section{H2a: Unsuccessful (successful) partner-level opinion-shopping increases (decreases) the probability of a firm switch.}

We do not formulate the corresponding hypothesis for partner-level switches, as a firmlevel switch necessarily implies a partner-level switch. When companies switch firms in an 
attempt to find a more lenient auditor, they already chose their preferred, most lenient, partnerfirm combination. Thus, after an unsuccessful firm switch, it is unlikely that they can find a different partner within the new firm that would be more lenient; and it would not be expected a subsequent attempt at the partner level. In those cases, we expect that the company escalates again, and eventually engages in another firm-level attempt (i.e., that it tries to find again a more permissive firm-partner combination). Therefore, we formulate our last hypothesis as follows:

\section{H2b: Unsuccessful (successful) firm-level opinion-shopping increases (decreases)} the probability of a firm switch.

\section{RESEARCH DESIGN}

\section{The Lennox's approach to test for opinion-shopping}

Similar to Chen et al. (2016), we employ the methodology developed by Lennox (2000) to study opinion-shopping. This methodology is based on the comparison of the predicted probabilities of getting a modified opinion that a company would had under different switching decisions. Opinion-shopping is consistent with a company switching (not switching) auditors when its expected probability of receiving a modified opinion if switching (if not switching) is lower than its expected probability of receiving a modified report if not switching (if switching). The Lennox's approach is implemented in two stages. In the first stage we estimate the audit reporting model specified in equation (1).

$$
\begin{aligned}
& O P_{i, t}=\alpha_{0}+\alpha_{1} \text { LagOP }_{i, t}+\alpha_{2} \text { SwitchVar }_{i, t}+\alpha_{3} \text { SwitchVar }^{*} \text { LagOP }_{i, t} \\
& +\alpha_{4} \text { Roa }_{i, t}+\alpha_{5} \text { Loss }_{i, t}+\alpha_{6} \text { Leverage }_{i, t}+\alpha_{7} \text { CR }_{i, t}+\alpha_{8} \text { ListAge }_{i, t} \\
& +\alpha_{9} \text { Size }_{i, t}+\alpha_{10} \text { ArInv }_{i, t}+\sum_{j=11}^{17} \alpha_{j} \text { SwitchVar }_{i, t} * X_{i, t}+\text { Year effects } \\
& + \text { Industry effects }+\varepsilon_{i, t}
\end{aligned}
$$


All the variable definitions are included in Appendix II. Model (1) is a probit regression where the dependent variable, $O P_{\mathrm{i}, \mathrm{t}}$, is a dummy that equals 1 when company $i$ receives a modified opinion in year $t$, and 0 otherwise. We consider any report without a clean opinion as modified. Adverse opinions or disclaimers of opinion are not considered, although results do not change if we consider them as modified opinions. The auditor switching variable in model (1), SwitchVar ${ }_{i, t}$, is defined as $S w i t c h P_{i, t}$ or $S w i t c h F_{i, t}$, which are dummies that equal 1 when company $i$ in year $t$ switches the partner or the firm respectively, and 0 otherwise. Our model includes several controls as identified in prior research (Carson, Fargher, Geiger, Lennox, Raghunandan and Willekens 2013). We control for the opinion persistence with the prior-year audit opinion $\left(\operatorname{LagOP} P_{i, t}\right)$. The company's performance is controlled with $\operatorname{Roa}_{i, t}$, calculated as net income over total assets for firm $i$ in year $t$; and $\operatorname{Loss}_{i, t}$, a dummy variable that equals 1 when company $i$ has an operating loss in year $t$, and 0 otherwise. Poorly performing firms are more likely to receive a modified opinion (DeFond, Raghunanadan and Subramanyam 2002). We additionally control for firm liquidity and financial condition with Leverage $_{i, t}$ (total debt over total assets of company $i$ in year $t$ ), $C R_{i, t}$ (current assets over current liabilities of company $i$ in year $t$ ), ListAge $e_{i, t}$ (number of years in year $t$ since the company $i$ 's equity lists), $\operatorname{ArInv}_{i, t}$ (accounts receivable plus inventory over total assets of company $i$ in year $t$ ), and Size $_{i, t}$ (natural logarithm of total sales of company $i$ in year $t$ ). Large, established firms with more cash, greater liquidity and lower leverage have more resources to stave off bankruptcy, and are less likely to receive a modified opinion (DeFond et al. 2002; Carey and Simnet 2006).

In model (1), the interaction term between the auditor switching variable and LagOP tests whether the switching significantly affects the audit reporting persistence. The interaction terms between the auditor switching variable and the other control variables (SwitchVar * Control) test 
whether the association between the corresponding control variable and the probability of receiving a modified opinion significantly differs between the switching and the non-switching companies. Finally, the model includes year and industry fixed effects. We cluster standard errors by company to control for time series dependence (Gow, Ormazabal and Taylor 2010).

From the estimation of model (1) we calculate the two opinion-shopping variables used in Lennox (2000) and Chen et al. (2016): (i) the difference between the predicted modified opinion probabilities conditioned to the switching decision. For each company $i$ and year $t$ OpnShopF is the difference between the predicted probability of receiving a modified opinion conditioned to a firm switch occurs $\left(\operatorname{Pr}\left(\widehat{O P}_{i, t}=1\right) \mid\right.$ SwitchF $\left.=1\right)$ and the predicted probability of receiving a modified opinion conditioned to not switching the firm $\left(\operatorname{Pr}\left(\widehat{O P}_{i, t}=1\right) \mid\right.$ SwitchF $\left.=0\right)$. OpnShopP is calculated identically but considering partner-level switching (SwitchP); and (ii) the difference between the predicted response variables: $O p n S h o p F 2=O P_{i, t}^{* 1 F}-O P_{i, t}^{* 0 F}$ and $O p n S h o p P 2=$ $O P_{i, t}^{* 1 P}-O P_{i, t}^{* 0 P}$

The intuition underlying the Lennox's approach is that opinion-shopping occurs if companies switch auditors when the probability of receiving a modified opinion with the switch is lower than if they retained the auditor. Also, opinion-shopping occurs if they do not switch the auditor when the probability of receiving a modified opinion with the auditor retention is lower than if they switched. Therefore, if opinion-shopping is a pervasive activity the relation between the corresponding opinion-shopping variable and the observed auditor switching behavior would

\footnotetext{
${ }^{9}$ The relation between the predicted response variable and the corresponding predicted probability is as follows: $\left[\operatorname{Pr}\left(\widehat{O P}_{i, t}=1\right) \mid\right.$ SwitchVar $\left.=\mathrm{d}\right]=\Phi\left[O P_{i, t}^{* d V a r}\right]$, where $\mathrm{d}=0$ or 1 and $\operatorname{Var}=F$ or $P$.
} 
be negative. This is tested in the second stage, where we estimate the probit regression specified in equation (2).

$$
\begin{aligned}
\text { SwitchVar }_{i, t} & =\alpha_{0}+\alpha_{1} \text { OpnShopVar }_{i, t}+\alpha_{2} \text { Roa }_{i, t}+\alpha_{3} \text { Loss }_{i, t}+\alpha_{4} \text { Leverage }_{i, t} \\
& +\alpha_{5} \text { CR }_{i, t}+\alpha_{6} \text { ListAge }_{i, t}+\alpha_{7} \text { Size }_{i, t}+\alpha_{8} \text { ArIn }_{i, t}+\alpha_{9} \text { Growt }_{i, t} \\
& +\alpha_{10} \text { TenureP }_{i, t}+\alpha_{11} \text { Tenure }_{i, t}+\alpha_{12} \text { Pexper }_{i, t}+\text { Year effects } \\
& + \text { Industry effects }+\varepsilon_{i, t}
\end{aligned}
$$

As in Chen et al. (2016) the auditor switching model includes controls for the client's characteristics (Roa, Loss, Leverage, CR, ListAge, Size, ArInv, and Growth) plus additional controls for the switching costs. In particular, we include: the tenure of both the audit partner and the audit firm, calculated as the number of years in $t$ since the firm, or the partner, audits the company $i$ up to year $t-1\left(\right.$ Tenure $_{i, t}$ and TenureP $\left._{i, t}\right)$; and a dummy variable Pexper $_{i, t}$ that equals 1 whether the partner of company $i$ in year $t$ is an industry expert, and 0 otherwise. We consider a partner to be an expert in a specific industry and year combination if she is the first or second ranked partner as per the proportion of clients' assets audited within that industry and year combination. Switching costs increase with both partner and firm tenure because the auditor's knowledge of the client increases with tenure; while if the new audit partner is an expert within the company's industry the switching costs are lower (Chi and Chin 2011; Hsieh and Lin 2015).

\section{Sample selection}

Table 1 summarizes our sample selection process. We focus on non-financial companies with listed equity since listed status is a determinant for auditor reporting behavior. Audit partner identity was hand-collected from the audit reports. The initial sample with available data on audit firm and partner switches and auditor opinion consists of 3,307 company-year observations for the period 1990-2014. Consolidated financial statements data necessary to calculate the research 
variables comes from SABI (Bureau Van Dijk). We lose 808 observations in the merge of the auditing and financial data. Given the need of reliable measures of firm and partner tenure, we also discard the first five years of data (294 observations). Therefore, our tests are based on the 20-year period 1995-2014. ${ }^{10}$ Following Lennox (2000) and Chen et al. (2016) we only consider voluntary auditor switches in our primary tests. Therefore, we eliminate: (1) 71 observations with forced firm switches. These correspond to firm mergers and acquisitions during the sample period. ${ }^{11}$ (2) 74 observations with mandatory partner rotation; ${ }^{12}$ and (3) 9 observations where the mandatory partner rotation rule is broken; ${ }^{13}$ The sample does not contain observations where the partner remains and the firm switches. This process results in a final sample of 2,051 observations belonging to 194 individual companies. We have an incomplete panel of companyyears where the average number of observations per company is 10.5 .

Table 1: Sample selection.

Observations

Initial audit sample (both firm and partner data plus audit opinion in $t$ and $t-1$.

Non-financial companies with listed equity. Period 1990-2014)

- Observations with no consolidated financial data available 808

- Observations of years 1990-1994

(deleted for the firm and partner tenure measurement)

- Forced firm switches

- Mandatory partner rotations

(after 2002 where salient partner tenure $>=7$ )

- Non-compliers with the mandatory partner rotation rule

(after 2002 where partner tenure $>7$ )

Final sample

\footnotetext{
${ }^{10}$ The sample represents a high percentage of the population. To illustrate, in December 2014 the number of nonfinancial Spanish companies with listed equity was 111,86 of which are included in the sample.

${ }^{11}$ Cases related to the demise of Arthur Andersen in 2002, acquired by DT; and to the merger of PriceWaterhouse and Coopers \& Lybrand in 1998.

${ }^{12}$ Given the regulatory setting described previously, we classify as mandatory those partner switches after 2002 where the salient partner's tenure is at least seven years. In a subsequent analysis we investigate the potential effects of regulation on the opinion-shopping activity by analyzing these observations.

${ }^{13}$ The 9 observations where the mandatory partner rotation rule is broken belong to 5 individual companies.
} 


\section{Descriptive statistics and correlations}

Modified opinions and firm- and partner-level switching rates over the sample period are plotted in Figure 2. Descriptive statistics of our research variables are presented in Table 2. The sample contains 443 observations where the audit report is modified ( 21.6 percent). This rate is higher in the earlier years, being the highest rate of 32.7 percent in 1995 and the lowest rate of 8.7 percent in $2007 .{ }^{14}$ We see that partner switches are more common than firm switches, which is similar to what Chen et al. (2016) report for China. However, our average auditor switching rates are lower than theirs. Chen et al. (2016) show a 36 and 12 percent switching rates at the partner and firm level respectively, while average firm (partner) switching is 6.2 (12.6) percent in our sample. The highest switching rate at the firm (partner) level is observed in year 2003 (2000), when 16.7 (22.7) percent of the companies switched their firm (partner).

To reduce the impact of outliers, all the continuous variables (Roa, Leverage, CR, Size, ArInv, and Growth) are winsorized at 1\% and 99\%. The sample contains the largest Spanish companies, with mean (median) sales of 2,340 (364) million Euros, and mean (median) annual sales growth rate of 15.5 (7.0) percent. The mean (median) Roa is 3.1 (3.7) percent, with 11.5 percent of the observations reporting operating losses (Loss). This is not surprising because the sample covers the whole economic crisis that began in 2008. The mean (median) Leverage is 0.617 (0.628); and the mean (median) values for the liquidity measures, $C R$ and $A r \operatorname{In} v$, are 1.558 (1.196) and $0.348(0.325)$ respectively. We also observe that the average partner (firm) tenure is 3.3 (6.7) years and that 3.2 percent of the sample is audited by an industry expert partner (Pexper).

\footnotetext{
${ }^{14}$ The rate of modified opinions in our sample is much higher than in other settings, like the U.S. or the U.K. Prior Spanish-based studies confirm this high rate of modified reports (e.g., Ruiz-Barbadillo et al. 2006).
} 
Figure 2: Auditor switches and modified opinion rates per year.

The graph plots the rates of partner and firm switching as well as the rate of modified opinions per year over the sample period (1995-2014).

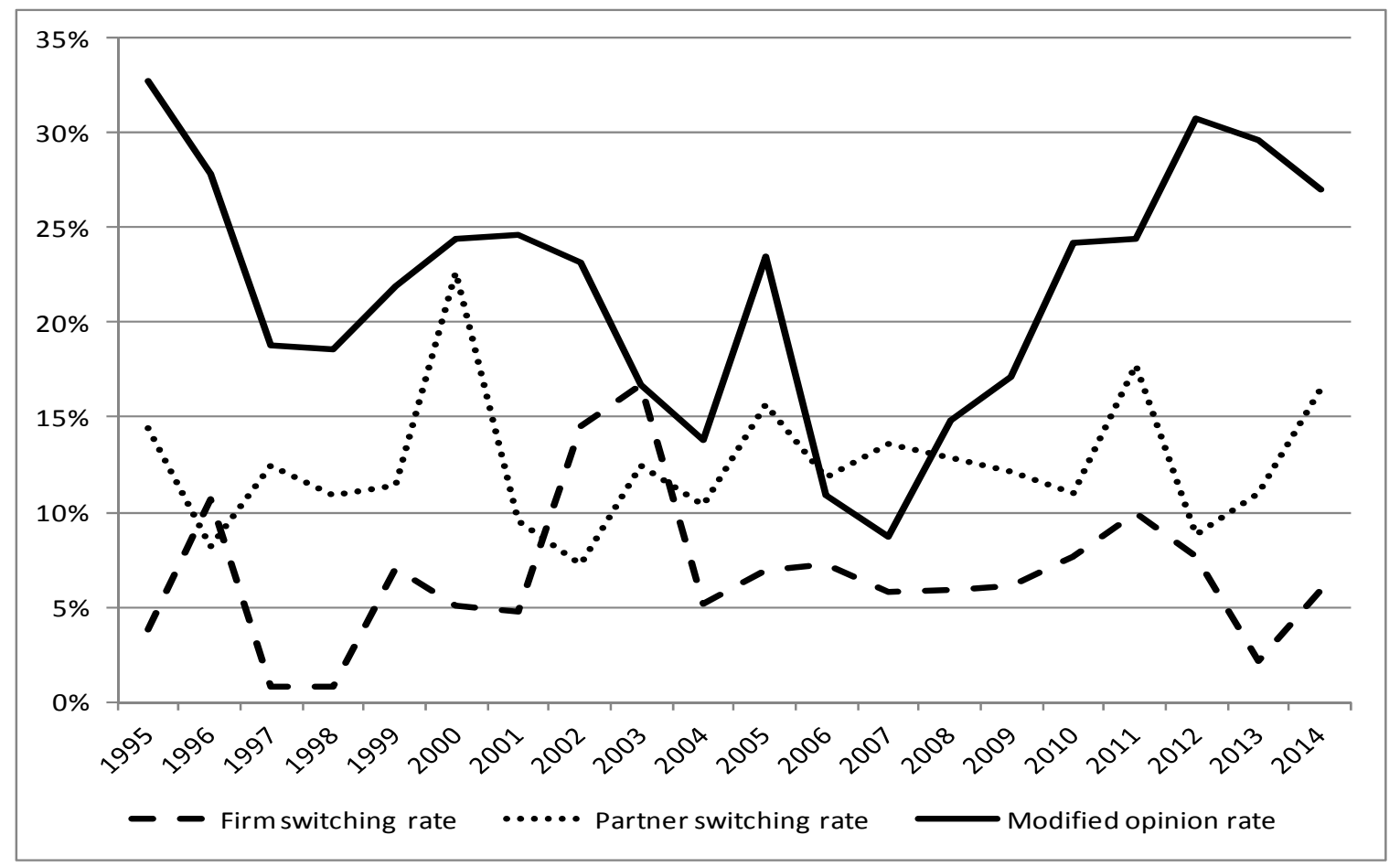

Table 2: Descriptive statistics of research variables.

Definitions of the research variables are in Appendix II.

\begin{tabular}{lrrrrrr}
\hline Variable & $\mathrm{N}$ & Mean & Median & Std. Dev. & P25 & P75 \\
\hline OP & 2,051 & 0.216 & 0.000 & 0.412 & 0.000 & 0.000 \\
SwitchF & 2,051 & 0.062 & 0.000 & 0.241 & 0.000 & 0.000 \\
SwitchP & 2,051 & 0.126 & 0.000 & 0.332 & 0.000 & 0.000 \\
Roa & 2,051 & 0.031 & 0.037 & 0.081 & 0.013 & 0.063 \\
Loss & 2,051 & 0.115 & 0.000 & 0.319 & 0.000 & 0.000 \\
Leverage & 2,051 & 0.617 & 0.628 & 0.217 & 0.478 & 0.767 \\
CR & 2,051 & 1.558 & 1.196 & 2.599 & 0.875 & 1.617 \\
ListAge & 2,051 & 14.566 & 14.000 & 6.797 & 9.000 & 20.000 \\
Sales(thousand $\epsilon)$ & 2,051 & $2,339,689$ & 364,435 & $6,949,950$ & 100,937 & $1,254,926$ \\
Size & 2,051 & 12.766 & 12.806 & 2.063 & 11.522 & 14.043 \\
ArInv & 2,051 & 0.348 & 0.325 & 0.208 & 0.178 & 0.492 \\
Growth & 2,051 & 0.155 & 0.070 & 0.560 & -0.024 & 0.180 \\
TenureP & 2,051 & 3.309 & 3.000 & 2.252 & 2.000 & 5.000 \\
TenureF & 2,051 & 6.728 & 6.000 & 4.381 & 3.000 & 9.000 \\
Pexper & 2,051 & 0.032 & 0.000 & 0.175 & 0.000 & 0.000 \\
\hline
\end{tabular}


Table 3 presents the Pearson correlations between our research variables. Spearman correlations offer similar results. The persistence in the auditor opinion in our sample is higher than in other settings, like the UK and China. Lennox (2000) and Chen et al. (2016) report a correlation between $O P$ and $\operatorname{Lag} O P$ of 40 percent and 55 percent in the UK and China respectively, while in our sample this correlation is 63 percent. The correlations between auditor switching and auditor opinion are of special interest: firm switching (SwitchF) is positively and significantly correlated to both $O P$ and $\operatorname{Lag} O P(\rho=0.08$ and $\rho=0.10)$, while partner switching $($ Switch $P)$ is not significantly correlated to the auditor opinion. 
Table 3: Correlations matrix.

The table shows Pearson correlations between pairs of the research variables. Correlations in bold are statistically significant at least at $5 \%$ level. Variables definitions are in Appendix II.

\begin{tabular}{|c|c|c|c|c|c|c|c|c|c|c|c|c|c|c|c|c|c|}
\hline & & (1) & (2) & (3) & (4) & $(5)$ & (6) & (7) & (8) & (9) & (10) & (11) & (12) & (13) & (14) & (15) & (16) \\
\hline (1) & $O P$ & 1.00 & & & & & & & & & & & & & & & \\
\hline (2) & LagOP & 0.63 & 1.00 & & & & & & & & & & & & & & \\
\hline (3) & SwitchF & 0.08 & 0.10 & 1.00 & & & & & & & & & & & & & \\
\hline (4) & SwitchP & -0.01 & -0.04 & -0.10 & 1.00 & & & & & & & & & & & & \\
\hline (5) & Roa & -0.36 & -0.28 & -0.04 & 0.01 & 1.00 & & & & & & & & & & & \\
\hline (6) & Loss & 0.32 & 0.29 & 0.03 & -0.00 & -0.56 & 1.00 & & & & & & & & & & \\
\hline (7) & Leverage & 0.22 & 0.18 & 0.05 & -0.00 & -0.30 & 0.15 & 1.00 & & & & & & & & & \\
\hline (8) & $C R$ & -0.05 & -0.03 & -0.04 & -0.01 & 0.02 & 0.07 & -0.39 & 1.00 & & & & & & & & \\
\hline (9) & ListAge & -0.00 & -0.02 & 0.00 & -0.01 & -0.15 & 0.11 & 0.14 & -0.07 & 1.00 & & & & & & & \\
\hline (10) & Sales & -0.09 & -0.11 & -0.02 & 0.02 & 0.07 & -0.10 & 0.08 & -0.06 & 0.20 & 1.00 & & & & & & \\
\hline (11) & Size & -0.20 & -0.23 & -0.05 & 0.02 & 0.18 & -0.27 & 0.21 & -0.29 & 0.13 & 0.54 & 1.00 & & & & & \\
\hline (12) & ArInv & 0.12 & 0.13 & 0.01 & 0.01 & 0.03 & 0.01 & 0.22 & -0.06 & -0.15 & -0.19 & -0.18 & 1.00 & & & & \\
\hline (13) & Growth & -0.02 & -0.02 & 0.03 & 0.01 & 0.09 & -0.12 & -0.00 & -0.01 & -0.13 & 0.01 & 0.03 & 0.04 & 1.00 & & & \\
\hline (14) & TenureP & -0.01 & -0.02 & 0.06 & 0.02 & 0.04 & -0.04 & -0.06 & 0.06 & -0.02 & -0.05 & -0.06 & 0.02 & 0.01 & 1.00 & & \\
\hline (15) & TenureF & -0.09 & -0.10 & 0.06 & -0.02 & 0.06 & -0.03 & -0.04 & 0.04 & 0.33 & 0.00 & 0.04 & 0.00 & -0.06 & 0.22 & 1.00 & \\
\hline (16) & Pexper & 0.11 & 0.09 & 0.01 & 0.06 & -0.11 & 0.10 & -0.04 & -0.01 & 0.04 & -0.06 & -0.25 & -0.02 & -0.03 & -0.06 & -0.00 & 1.00 \\
\hline
\end{tabular}




\section{RESULTS AND DISCUSSION}

\section{Main results}

We present the results of the audit reporting model estimation in Table 4. In column (1) we show the results obtained without the auditor switching variables; column (2) includes the switching variable at the firm level (SwitchF) and its interaction with the rest of the regressors; and column (3) shows the same with the partner switching variable (SwitchP). The strong persistence of the audit opinion is reflected in the positive and significant coefficient of LagOP in the three models. In column (2) we see that the interaction of SwitchF and LagOP is negative and statistically significant. This is in line with the Lennox's (2000) finding at the firm level in the UK and with the Chen et al. (2016) finding at the partner level in China, and suggests that a firm switch reduces the persistence of the audit opinion, which is consistent with opinion-shopping activity. In column (3) we observe the opposite at the partner level, since the interaction of SwitchP and LagOP is positive. As per the control variables, the results are consistent with the prior literature: the company's profitability and size negatively relate to the probability of a modified opinion while leverage is positively related.

From the results of the audit reporting model estimation we compute the predicted probabilities of modified opinions conditioned to the different auditor switching scenarios. The mean values of these predicted probabilities are reported in Table 5. In Panel A we look at cases when prior reports are modified (443 observations), while Panel B shows the results for the 1,608 observations with a clean opinion in $t-1$. When the prior year opinion is modified, companies receive modified reports with lower probabilities if they switch the firm than if they do not (65.7 versus 71.4 percent). In contrast, when the prior year opinion is clean, companies 
Table 4: Audit reporting model.

This table shows the results of the probit regression in model (1). Column (1) does not include the switching variables, while columns (2) and (3) include SwitchF and SwitchP respectively and their interactions with the rest of the regressors. $Z$-statistics, corrected by time series dependence, appear below the estimated coefficients. Variables definitions are in Appendix II. Statistical significance is indicated by $*$ p-value $<0.1, * * p$-value $<0.05$, and $* * * p$ value $<0.01$.

\begin{tabular}{|c|c|c|c|}
\hline Variables & $\begin{array}{l}(1) \\
O P\end{array}$ & $\begin{array}{l}\text { (2) } \\
O P\end{array}$ & $\begin{array}{l}\text { (3) } \\
O P\end{array}$ \\
\hline \multirow{2}{*}{ Constant } & $-1.342 * *$ & $-1.366 * *$ & $-1.345^{* *}$ \\
\hline & {$[-2.50]$} & {$[-2.47]$} & {$[-2.33]$} \\
\hline \multirow{2}{*}{$\operatorname{LagOP}$} & $1.794 * * *$ & $1.865 * * *$ & $1.745^{* * *}$ \\
\hline & [14.36] & [15.43] & [13.34] \\
\hline \multirow[t]{2}{*}{ SwitchF } & & -0.149 & \\
\hline & & {$[-0.13]$} & \\
\hline SwithP & & & $\begin{array}{c}0.384 \\
{[0.33]}\end{array}$ \\
\hline \multirow[t]{2}{*}{ SwitchVar*LagOP } & & $-0.648 * *$ & $0.486^{*}$ \\
\hline & & {$[-2.09]$} & {$[1.75]$} \\
\hline \multirow[t]{2}{*}{ Roa } & $-4.297 * * *$ & $-4.496 * * *$ & $-4.045 * * *$ \\
\hline & {$[-6.16]$} & {$[-5.95]$} & {$[-5.51]$} \\
\hline \multirow[t]{2}{*}{ Loss } & $0.260^{*}$ & 0.203 & $0.299 *$ \\
\hline & {$[1.70]$} & {$[1.25]$} & {$[1.86]$} \\
\hline \multirow[t]{2}{*}{ Leverage } & $0.758 * * *$ & $0.816 * * *$ & $0.808 * * *$ \\
\hline & [2.63] & [2.73] & [2.73] \\
\hline \multirow[t]{2}{*}{$C R$} & -0.025 & -0.027 & -0.027 \\
\hline & {$[-1.42]$} & {$[-1.41]$} & {$[-1.51]$} \\
\hline \multirow{2}{*}{ ListAge } & -0.002 & -0.005 & -0.006 \\
\hline & {$[-0.28]$} & {$[-0.61]$} & {$[-0.65]$} \\
\hline \multirow[t]{2}{*}{ Size } & $-0.046^{*}$ & -0.042 & -0.045 \\
\hline & {$[-1.80]$} & {$[-1.63]$} & {$[-1.62]$} \\
\hline \multirow[t]{2}{*}{$\operatorname{ArInv}$} & 0.366 & 0.222 & 0.322 \\
\hline & {$[1.50]$} & {$[0.85]$} & {$[1.24]$} \\
\hline \multirow[t]{2}{*}{ SwitchVar*Roa } & & 1.285 & -2.478 \\
\hline & & {$[0.77]$} & {$[-1.36]$} \\
\hline \multirow[t]{2}{*}{ SwitchVar*Loss } & & 0.597 & -0.461 \\
\hline & & {$[1.20]$} & {$[-1.07]$} \\
\hline \multirow[t]{2}{*}{ SwitchVar*Leverage } & & -0.002 & $-0.004 * *$ \\
\hline & & {$[-1.06]$} & {$[-2.56]$} \\
\hline \multirow[t]{2}{*}{ SwitchVar ${ }^{*} C R$} & & 0.152 & -0.013 \\
\hline & & {$[0.78]$} & {$[-0.14]$} \\
\hline \multirow[t]{2}{*}{ SwitchVar*ListAge } & & $0.038^{*}$ & 0.024 \\
\hline & & {$[1.75]$} & {$[1.13]$} \\
\hline \multirow{2}{*}{ SwitchVar*Size } & & -0.051 & -0.046 \\
\hline & & {$[-0.68]$} & {$[-0.62]$} \\
\hline \multirow[t]{2}{*}{ SwitchVar*ArInv } & & 0.966 & -0.041 \\
\hline & & {$[1.41]$} & {$[-0.06]$} \\
\hline Year controls & Yes & Yes & Yes \\
\hline Industry controls & Yes & Yes & Yes \\
\hline N. Observations & 2,051 & 2,051 & 2,051 \\
\hline $\operatorname{LR} \chi_{2}$ & $699.33 * * *$ & $765.28 * * *$ & $713.78 * * *$ \\
\hline Pseudo- $\mathrm{R}^{2}$ & 0.417 & 0.425 & 0.425 \\
\hline
\end{tabular}


receive modified opinions in $\mathrm{t}$ with significantly lower probability if they do not switch the firm (7.7 percent in the firm retaining scenario versus 15.1 percent in the firm switching scenario). Therefore, opinion-shopping companies would change the firm more frequently when the prior report is modified. At the partner level we observe a different pattern. When the opinion in $\mathrm{t}-1$ is modified, companies receive a modified report in $t$ with significantly lower probably if they do not switch the partner (69.4 percent) than if the partner switches ( 80.8 percent). Remarkably, the highest average predicted probability of a modified opinion is observed in the partner switching scenario of this group. When the opinion in $\mathrm{t}-1$ is clean, we also observe that companies receive a modified report with significantly lower probably if the partner does not switch, although in this case the difference between the mean expected probabilities conditioned to the switching and the non-switching partner scenarios is small ( 8.3 percent versus 8.1 percent). Thus, opinionshoppers would not change the partner in any case. Overall, results in Table 5 are consistent with firm-level but not partner-level opinion-shopping.

Table 5: Mean predicted probabilities of modified opinions conditioned to the audit switching decision.

Panel A shows the mean predicted probabilities of a modified opinion in year $t$ if the opinion in year $t-1$ is modified conditioned to the auditor switching decision, both at the firm and partner levels. Additionally, we report the $t$ statistics of the $t$-tests which null is that the two means are equal. Statistical significance is indicated by * $\mathrm{p}$-value $<$ $0.1, * * \mathrm{p}$-value $<0.05$, and $* * * \mathrm{p}$-value $<0.01$. Panel B shows the same when the opinion in $t-1$ is clean. Variables definitions are in Appendix II.

Panel A: Prior opinions are modified (443 observations)

\begin{tabular}{lrr}
\hline & \multicolumn{1}{c}{ SwitchF } & SwitchP \\
\cline { 2 - 3 } Mean $\operatorname{Prob}(\widehat{O P}=1 \mid$ Switch $=1)$ & $65.7 \%$ & $80.8 \%$ \\
Mean $\operatorname{Prob}(\widehat{O P}=1 \mid$ Switch $=0)$ & $71.4 \%$ & $69.4 \%$ \\
\hline Diff test $(t$-statistic $)$ & $-8.11^{* * *}$ & $30.10^{* * *}$ \\
\hline Panel B: Prior opinions are clean $(1,608$ observations $)$ & & \\
\hline & & SwitchP \\
Mean Prob $(\widehat{O P}=1 \mid$ Switch $=1)$ & $15.1 \%$ & $8.3 \%$ \\
Mean $\operatorname{Prob}(\widehat{O P}=1 \mid$ Switch $=0)$ & $7.7 \%$ & $8.1 \%$ \\
\hline Diff test $(t$-statistic $)$ & $24.74 * * *$ & $2.00^{* *}$ \\
\hline
\end{tabular}


Table 6 shows the results of the auditor switching models' estimation, which confirm the evidence of Table 5. In the firm switching models, reported in columns (1) and (2), the coefficients of the opinion-shopping variables (OpnShopF and OpnShopF2) are negative and significant at least at the 5\% level; while in the partner switching models, shown in columns (3) and (4), OpnShopP and OpnShopP2 are negative but only the second is weakly statistically significant, at the $10 \%$ level. Moreover, the results reported in columns (5) and (6) indicate that $\operatorname{LagOP}$ is positively and significantly related to firm switching at the $1 \%$ level, while it is negatively related to partner switching at the $10 \%$ significance level.

Overall, the results presented in this section are consistent with our predictions. They support the thesis that attempts to opinion-shop at the firm level are successful. Companies would have received more unfavorable opinions had they made alternative firm switching decisions. However, in contrast with the findings of Chen et al. (2016) in the Chinese setting, we find no evidence of successful opinion-shopping at the partner level. This contrasting evidence is consistent with our predictions, based on the explained different characteristics of the considered settings. 
Table 6: Auditor switching models.

The table shows the results of the estimation of model (2), both at the firm and the partner level, and using the two alternative opinion-shopping variables (Columns 1 to 4). Columns (5) and (6) show the results of the probit regressions where audit firm and partner switching is explained by the prior year opinion $(\operatorname{LagOP})$ and other controls. $Z$-statistics, corrected by time series dependence, are reported below the estimated coefficients. Variables definitions are in Appendix II. Statistical significance is indicated by $*$ p-value $<0.1, * * \mathrm{p}$-value $<0.05$, and $* * * \mathrm{p}-$ value $<0.01$

\begin{tabular}{|c|c|c|c|c|c|c|}
\hline Variables & $\begin{array}{r}(1) \\
\text { SwitchF }\end{array}$ & $\begin{array}{r}\text { (2) } \\
\text { SwitchF }\end{array}$ & $\begin{array}{r}\text { (3) } \\
\text { SwitchP }\end{array}$ & $\begin{array}{r}\text { (4) } \\
\text { SwitchP }\end{array}$ & $\begin{array}{r}(5) \\
\text { SwitchF }\end{array}$ & $\begin{array}{r}\text { (6) } \\
\text { SwitchP }\end{array}$ \\
\hline Constant & $\begin{array}{l}-0.186 \\
{[-0.31]}\end{array}$ & $\begin{array}{l}-0.356 \\
{[-0.59]}\end{array}$ & $\begin{array}{r}-1.193 * * \\
{[-2.23]}\end{array}$ & $\begin{array}{r}-1.036^{*} \\
{[-1.89]}\end{array}$ & $\begin{array}{l}-0.290 \\
{[-0.48]}\end{array}$ & $\begin{array}{r}-1.191 * * \\
{[-2.26]}\end{array}$ \\
\hline OpnShopF & $\begin{array}{r}-1.262 * * \\
{[-2.41]}\end{array}$ & & & & & \\
\hline OpnShopF2 & & $\begin{array}{r}-0.672 * * * \\
{[-4.11]}\end{array}$ & & & & \\
\hline OpnShopP & & & $\begin{array}{r}-0.600 \\
{[-0.97]}\end{array}$ & & & \\
\hline OpnShopP2 & & & & $\begin{array}{r}-0.404 * \\
{[-1.90]}\end{array}$ & & \\
\hline LagOP & & & & & $\begin{array}{r}0.435 * * * \\
{[4.11]}\end{array}$ & $\begin{array}{r}-0.196^{*} \\
{[-1.90]}\end{array}$ \\
\hline Roa & $\begin{array}{l}-0.003 \\
{[-0.00]}\end{array}$ & $\begin{array}{c}0.658 \\
{[0.80]}\end{array}$ & $\begin{array}{c}0.117 \\
{[0.18]}\end{array}$ & $\begin{array}{l}-0.798 \\
{[-0.92]}\end{array}$ & $\begin{array}{l}-0.205 \\
{[-0.28]}\end{array}$ & $\begin{array}{c}0.204 \\
{[0.32]}\end{array}$ \\
\hline Loss & $\begin{array}{c}0.215 \\
{[1.12]}\end{array}$ & $\begin{array}{c}0.336^{*} \\
{[1.79]}\end{array}$ & $\begin{array}{c}0.012 \\
{[0.08]}\end{array}$ & $\begin{array}{l}-0.092 \\
{[-0.53]}\end{array}$ & $\begin{array}{c}-0.065 \\
{[-0.44]}\end{array}$ & $\begin{array}{r}0.094 \\
{[0.66]}\end{array}$ \\
\hline Leverage & $\begin{array}{c}0.006 \\
{[0.02]}\end{array}$ & $\begin{array}{l}-0.131 \\
{[-0.44]}\end{array}$ & $\begin{array}{c}-0.092 \\
{[-0.45]}\end{array}$ & $\begin{array}{l}-0.043 \\
{[-0.21]}\end{array}$ & $\begin{array}{l}-0.129 \\
{[-0.44]}\end{array}$ & $\begin{array}{l}-0.042 \\
{[-0.20]}\end{array}$ \\
\hline$C R$ & $\begin{array}{l}-0.115 \\
{[-1.37]}\end{array}$ & $\begin{array}{r}-0.060 \\
{[-0.70]}\end{array}$ & $\begin{array}{r}-0.009 \\
{[-0.52]}\end{array}$ & $\begin{array}{c}-0.014 \\
{[-0.76]}\end{array}$ & $\begin{array}{c}-0.162^{*} \\
{[-1.96]}\end{array}$ & $\begin{array}{l}-0.009 \\
{[-0.51]}\end{array}$ \\
\hline ListAge & $\begin{array}{l}-0.006 \\
{[-0.62]}\end{array}$ & $\begin{array}{c}0.008 \\
{[0.77]}\end{array}$ & $\begin{array}{r}-0.006 \\
{[-0.68]}\end{array}$ & $\begin{array}{c}0.002 \\
{[0.25]}\end{array}$ & $\begin{array}{r}-0.017 * * \\
{[-2.12]}\end{array}$ & $\begin{array}{l}-0.007 \\
{[-0.91]}\end{array}$ \\
\hline Size & $\begin{array}{r}-0.096^{* * *} \\
{[-3.05]}\end{array}$ & $\begin{array}{r}-0.107 * * * \\
{[-3.48]}\end{array}$ & $\begin{array}{r}0.027 \\
{[1.06]}\end{array}$ & $\begin{array}{r}0.008 \\
{[0.30]}\end{array}$ & $\begin{array}{r}-0.072 * * \\
{[-2.29]}\end{array}$ & $\begin{array}{l}0.027 \\
{[1.11]}\end{array}$ \\
\hline $\operatorname{ArIn} v$ & $\begin{array}{c}0.302 \\
{[1.04]}\end{array}$ & $\begin{array}{r}0.668 * * \\
{[2.11]}\end{array}$ & $\begin{array}{c}0.111 \\
{[0.56]}\end{array}$ & $\begin{array}{c}0.121 \\
{[0.61]}\end{array}$ & $\begin{array}{r}0.020 \\
{[0.07]}\end{array}$ & $\begin{array}{r}0.137 \\
{[0.70]}\end{array}$ \\
\hline Growth & $\begin{array}{r}0.148^{* *} \\
{[2.24]}\end{array}$ & $\begin{array}{r}0.143^{* *} \\
{[2.20]}\end{array}$ & $\begin{array}{r}0.026 \\
{[0.46]}\end{array}$ & $\begin{array}{r}0.026 \\
{[0.45]}\end{array}$ & $\begin{array}{r}0.143 * * \\
{[2.20]}\end{array}$ & $\begin{array}{r}0.026 \\
{[0.45]}\end{array}$ \\
\hline TenureP & $\begin{array}{r}0.053 * * * \\
{[2.63]}\end{array}$ & $\begin{array}{r}0.053 * * \\
{[2.65]}\end{array}$ & $\begin{array}{c}0.030^{*} \\
{[1.71]}\end{array}$ & $\begin{array}{r}0.029 \\
{[1.64]}\end{array}$ & $\begin{array}{r}0.053 * * * \\
{[2.65]}\end{array}$ & $\begin{array}{c}0.029 \\
{[1.64]}\end{array}$ \\
\hline TenureF & $\begin{array}{r}0.034 * * * \\
{[3.05]}\end{array}$ & $\begin{array}{r}0.036 * * * \\
{[3.30]}\end{array}$ & $\begin{array}{l}-0.013 \\
{[-1.34]}\end{array}$ & $\begin{array}{l}-0.014 \\
{[-1.42]}\end{array}$ & $\begin{array}{r}0.036^{* * *} \\
{[3.30]}\end{array}$ & $\begin{array}{l}-0.014 \\
{[-1.42]}\end{array}$ \\
\hline Pexper & $\begin{array}{l}-0.167 \\
{[-0.66]}\end{array}$ & $\begin{array}{r}-0.186 \\
{[-0.77]}\end{array}$ & $\begin{array}{r}0.566^{* * * *} \\
{[2.64]}\end{array}$ & $\begin{array}{r}0.577 * * * \\
{[2.64]}\end{array}$ & $\begin{array}{l}-0.186 \\
{[-0.77]}\end{array}$ & $\begin{array}{r}0.577 * * * \\
{[2.64]}\end{array}$ \\
\hline Year effects & Yes & Yes & Yes & Yes & Yes & Yes \\
\hline Industry effects & Yes & Yes & Yes & Yes & Yes & Yes \\
\hline Observations & 2,051 & 2,051 & 2,051 & 2,051 & 2,051 & 2,051 \\
\hline LR $\chi^{2}$ & $96.39 * * *$ & $104.12 * * *$ & $57.39 * *$ & $63.43 * *$ & $104.12 * * *$ & $63.43^{* * *}$ \\
\hline Pseudo $\mathrm{R}^{2}$ & 0.098 & 0.106 & 0.026 & 0.028 & 0.106 & 0.028 \\
\hline
\end{tabular}




\section{Auditor switching and changes in auditor opinion}

In this section, we offer additional evidence by relating auditor switches and changes in the audit opinion. As Lennox (2000) indicates, finding no evidence of more favorable opinions after an auditor switch does not preclude opinion-shopping; however, the opposite is true, i.e., finding evidence of more favorable opinions after the switching would indicate opinion-shopping activity. Tables 7 and 8 contain the results of these tests, where we distinguish between opinion upgrades (i.e. a change from a modified to a clean report) and downgrades (i.e. a change from a clean to a modified report), since the effective opinion-shopping argument relates to opinion upgrades after the switch, and not to opinion downgrades. These, a priori, should be orthogonal to the switching decision.

As shown in column (1) of Table 7, the proportion of prior year modified opinions in the group of firm switchers is 37.8 percent, significantly higher than the 21.1 percent observed in the group of observations with no auditor switch. In turn, the proportion of modified opinions in the partner switching group (17.1) is not significantly different from the non-switchers group. These results are in line with those presented in Table 6, and suggest that modified reports relate to subsequent firm switches but not to subsequent partner switches. However, this finding does not necessarily indicate successful opinion-shopping. The evidence of opinion-shopping activity is shown in column (2) of Table 7, where we see that in the firm switching group the proportion of opinion upgrades is significantly greater than in the non-switching group (12.6 versus 6.4 percent). In contrast, the proportion of opinion upgrades in the partner switching group (3.1 percent) is significantly lower than in the non-switching group, consistent with a fresh eye effect associated with voluntary partner switches. We also observe, in column (3), that there are no 
statistically significant differences between the three groups in the proportion of opinion

downgrades.

Table 7: Auditor switching and changes in auditor opinion. Univariate evidence.

This table shows the proportion of companies with modified and clean opinions in year $t-1$ (column 1) within the three categories of auditor switching included in the sample: (i) no auditor switch; (ii) firm switches; and (iii) partner switches. The table also presents the proportion of companies where the opinion from year $t$ - 1 to year $t$ is upgraded (column 2), or downgraded (column 3). The last four rows of the table show the results of the proportion tests where the null hypothesis is that the proportions in the corresponding pair of categories are equal. Statistical significance (two tail tests) is indicated by * for $\mathrm{p}$-value $<0.10$; ** for $\mathrm{p}$-value $<0.05$; and $* * *$ for $\mathrm{p}$-value $<0.01$.

\begin{tabular}{|c|c|c|c|c|c|}
\hline \multirow{2}{*}{ Auditor switching } & & & \multirow{2}{*}{$\operatorname{LagOP=1}$} & $\begin{array}{r}\text { Change i } \\
\text { (2) }\end{array}$ & opinion \\
\hline & & & & $O P=0 \& \operatorname{Lag} O P=1$ & $O P=1 \& \operatorname{Lag} O P=0$ \\
\hline \multirow[t]{2}{*}{ All } & $\mathrm{N}$ & 2,051 & 443 & 130 & 130 \\
\hline & $\%$ & & $21.6 \%$ & $6.3 \%$ & $6.3 \%$ \\
\hline \multirow[t]{2}{*}{ (i) No auditor switch } & $\mathrm{N}$ & 1,666 & 351 & 106 & 100 \\
\hline & $\%$ & & $21.1 \%$ & $6.4 \%$ & $6.0 \%$ \\
\hline \multirow[t]{2}{*}{ (ii) Firm switches } & $\mathrm{N}$ & 127 & 48 & 16 & 12 \\
\hline & $\%$ & & $37.8 \%$ & $12.6 \%$ & $9.4 \%$ \\
\hline \multirow[t]{2}{*}{ (iii) Partner switches } & $\mathrm{N}$ & 258 & 44 & 8 & 18 \\
\hline & $\%$ & & $17.1 \%$ & $3.1 \%$ & $7.0 \%$ \\
\hline \multicolumn{3}{|c|}{ Difference in proportions (Z-statistics): } & & & \\
\hline \multirow{2}{*}{\multicolumn{3}{|c|}{ (i) vs (ii) }} & $-4.37 * * *$ & $-3.62 * * *$ & -1.55 \\
\hline & & & 1.48 & $2.07 * *$ & -0.61 \\
\hline \multicolumn{3}{|c|}{ (ii) vs (iii) } & $-4.49 * * *$ & $-2.69 * * *$ & -0.85 \\
\hline
\end{tabular}

We also conduct a multivariate regression analysis where the change in the audit opinion, either upgrading or downgrading, is expressed as a function of firm and partner switches and company and auditor characteristics, as specified in model (3). In particular, we control for changes in the company's profitability ( $\triangle$ Roa, Loss and LagLoss), financial condition ( $\Delta$ Leverage, $\Delta C R$, and $\Delta A r I n v)$, and size $(\Delta$ Size $)$, as well as for the type of audit firm (Big, LagBig, and TenureF) and partner (Pexper, LagPexper, TenureP). A changes specification allows us to make inferences about causality, and reduces the omitted-variable bias. 


$$
\begin{aligned}
O P_{-} U p_{i, t}\left(\operatorname{or} O P_{-} \text {Down }_{i, t}\right) & =\alpha_{0}+\alpha_{1} \text { SwitchVar }_{i, t}+\alpha_{2} \Delta \text { Roa }_{i, t}+\alpha_{3} \text { LLeverage }_{i, t} \\
& +\alpha_{4} \Delta \text { CR }_{i, t}+\alpha_{5} \Delta \text { Size }_{i, t}+\alpha_{6} \Delta \text { ArInv }_{i, t}+\alpha_{7} \text { Loss }_{i, t} \\
& +\alpha_{8} \text { LagLoss }_{i, t}+\alpha_{9} \text { Big }_{i, t}+\alpha_{10} \text { LagBig }_{i, t}+\alpha_{11} \text { Pexper }_{i, t} \\
& +\alpha_{12} \text { LagPexper }_{i, t}+\alpha_{13} \text { TenureP }_{i, t}+\alpha_{14} \text { TenureF }_{i, t} \\
& + \text { Year effects }+ \text { Industry effects }+\varepsilon_{i, t}
\end{aligned}
$$

Table 8 presents the results of the estimation of model (3) using $O P_{-} U p_{i, t}$ and OP_Down $n_{i, t}$ as the dependent variable, where the first is a dummy that equals 1 when company $i$ had a modified report in year $t-1$ and a clean report in year $t$, and 0 otherwise; and the second is a dummy that equals 1 when company $i$ had a clean report in year $t-1$ and a modified one in year $t$, and 0 otherwise. The probit estimations indicate that the probability of receiving an opinion upgrade is positively (negatively) and significantly associated with firm (partner) switching: in the $O P_{-} U p$ regressions, reported in columns (1) and (2), the coefficient of SwitchF is positive and statistically significant at $1 \%$, while the coefficient of SwitchP is negative and statistically significant at 5\%. These results are consistent with opinion-shopping (a fresh eyes effect) at the firm (partner) level. The new firm (partner) seems more (less) prone to issue a clean report if the company received a modified opinion from the prior firm (partner). In turn, neither SwitchF nor Switch $P$ are significant in the $O P \_$Down models. This result helps us to discard serious omitted variables bias, since the opinion-shopping argument only regards to opinion upgrading after the auditor switch.

This is the first study providing evidence that post auditor switch opinions are more favorable than pre-switch opinions. Lennox (2000) indicates that prior studies fail in finding this type of evidence because pre-switch opinions are not good proxies for the reports that companies had received under opposite switching decisions. This is probably not the case in our setting, as 
suggested by the higher persistence of the audit opinion observed, as compared to that reported in other studies, including that in the UK setting analyzed by Lennox (2000).

Table 8: Auditor switching and changes in auditor opinion. Regression results.

This table shows the results of the estimation of model (3) with $O P_{-} U_{p}$ (columns 1 and 2) and OP_Down (columns 3 and 4 ) as the dependent variable. $Z$-statistics, corrected by time series dependence, are reported below the estimated coefficients. Statistical significance of the coefficients is indicated by $*$ p-value $<0.1, * *$ p-value $<0.05$, and $* * *$ p-value $<0.01$. Variables definitions are in Appendix II.

\begin{tabular}{|c|c|c|c|c|}
\hline Variables & $\begin{array}{r}(1) \\
O P_{-} U p \\
\end{array}$ & $\begin{array}{r}(2) \\
O P_{-} U p \\
\end{array}$ & $\begin{array}{r}(3) \\
\text { OP_Down } \\
\end{array}$ & $\begin{array}{r}(4) \\
\text { OP_Down } \\
\end{array}$ \\
\hline Constant & $\begin{array}{r}-1.299 * * * \\
{[-3.89]}\end{array}$ & $\begin{array}{r}-1.221 * * * \\
{[-3.59]}\end{array}$ & $\begin{array}{r}-1.694 * * * \\
{[-4.38]}\end{array}$ & $\begin{array}{r}-1.680 * * * \\
{[-4.39]}\end{array}$ \\
\hline SwitchF & $\begin{array}{r}0.387 * * * \\
{[2.63]}\end{array}$ & & $\begin{array}{c}0.201 \\
{[1.09]}\end{array}$ & \\
\hline SwitchP & & $\begin{array}{r}-0.377 * * \\
{[-2.33]}\end{array}$ & & $\begin{array}{c}0.024 \\
{[0.18]}\end{array}$ \\
\hline$\Delta R o a$ & $\begin{array}{r}1.189 * * \\
{[2.03]}\end{array}$ & $\begin{array}{r}1.258^{* *} \\
{[2.14]}\end{array}$ & $\begin{array}{r}-1.939 * * * \\
{[-2.58]}\end{array}$ & $\begin{array}{r}-1.922 * * \\
{[-2.56]}\end{array}$ \\
\hline$\Delta$ Leverage & $\begin{array}{l}-0.000 \\
{[-0.75]}\end{array}$ & $\begin{array}{l}-0.000 \\
{[-0.86]}\end{array}$ & $\begin{array}{c}-0.000 \\
{[-0.74]}\end{array}$ & $\begin{array}{c}-0.000 \\
{[-0.75]}\end{array}$ \\
\hline$\triangle C R$ & $\begin{array}{r}0.053 * * \\
{[2.00]}\end{array}$ & $\begin{array}{c}0.052^{*} \\
{[1.93]}\end{array}$ & $\begin{array}{l}-0.025 \\
{[-1.28]}\end{array}$ & $\begin{array}{l}-0.024 \\
{[-1.28]}\end{array}$ \\
\hline$\Delta$ Size & $\begin{array}{r}0.232 * * * \\
{[2.91]}\end{array}$ & $\begin{array}{r}0.244 * * * \\
{[3.03]}\end{array}$ & $\begin{array}{r}0.160^{*} \\
{[1.82]}\end{array}$ & $\begin{array}{c}0.163^{*} \\
{[1.83]}\end{array}$ \\
\hline$\Delta A r I n v$ & $\begin{array}{l}-0.231 \\
{[-0.37]}\end{array}$ & $\begin{array}{c}-0.204 \\
{[-0.31]}\end{array}$ & $\begin{array}{l}-0.714 \\
{[-1.09]}\end{array}$ & $\begin{array}{l}-0.682 \\
{[-1.28]}\end{array}$ \\
\hline Loss & $\begin{array}{c}0.327^{*} \\
{[1.80]}\end{array}$ & $\begin{array}{c}0.342^{*} \\
{[1.86]}\end{array}$ & $\begin{array}{r}0.459 * * \\
{[2.47]}\end{array}$ & $\begin{array}{r}0.456^{* *} \\
{[2.47]}\end{array}$ \\
\hline LagLoss & $\begin{array}{r}0.180 \\
{[1.05]}\end{array}$ & $\begin{array}{r}0.176 \\
{[1.03]}\end{array}$ & $\begin{array}{l}-0.006 \\
{[-0.03]}\end{array}$ & $\begin{array}{c}0.005 \\
{[0.03]}\end{array}$ \\
\hline Big & $\begin{array}{r}-0.689 * * \\
{[-2.32]}\end{array}$ & $\begin{array}{r}-0.817 * * \\
{[-2.22]}\end{array}$ & $\begin{array}{c}0.336 \\
{[0.98]}\end{array}$ & $\begin{array}{c}0.422 \\
{[1.15]}\end{array}$ \\
\hline LagBig & $\begin{array}{c}0.649^{*} \\
{[1.82]}\end{array}$ & $\begin{array}{r}0.767^{*} \\
{[1.72]}\end{array}$ & $\begin{array}{l}-0.368 \\
{[-1.18]}\end{array}$ & $\begin{array}{l}-0.473 \\
{[-1.43]}\end{array}$ \\
\hline Pexper & $\begin{array}{l}-0.236 \\
{[-0.53]}\end{array}$ & $\begin{array}{c}-0.237 \\
{[-0.54]}\end{array}$ & $\begin{array}{c}0.310 \\
{[0.70]}\end{array}$ & $\begin{array}{c}0.323 \\
{[0.71]}\end{array}$ \\
\hline LagPexper & $\begin{array}{r}0.048 \\
{[0.11]}\end{array}$ & $\begin{array}{c}0.058 \\
{[0.14]}\end{array}$ & $\begin{array}{l}-0.529 \\
{[-1.02]}\end{array}$ & $\begin{array}{l}-0.546 \\
{[-1.04]}\end{array}$ \\
\hline LagTenureP & $\begin{array}{r}0.007 \\
{[0.30]}\end{array}$ & $\begin{array}{c}0.011 \\
{[0.47]}\end{array}$ & $\begin{array}{r}0.020 \\
{[0.99]}\end{array}$ & $\begin{array}{c}0.021 \\
{[1.00]}\end{array}$ \\
\hline LagTenureF & $\begin{array}{r}-0.026^{* *} \\
{[-1.98]}\end{array}$ & $\begin{array}{r}-0.025^{* *} \\
{[-2.02]}\end{array}$ & $\begin{array}{r}-0.023^{*} \\
{[-1.79]}\end{array}$ & $\begin{array}{c}-0.022^{*} \\
{[-1.72]}\end{array}$ \\
\hline Year effects & Yes & Yes & Yes & Yes \\
\hline Industry effects & Yes & Yes & Yes & Yes \\
\hline Observations & 2,051 & 2,051 & 2,051 & 2,051 \\
\hline LR $\chi^{2}$ & $138.91 * * *$ & $138.90 * * *$ & $110.30 * * *$ & $101.68 * * *$ \\
\hline Pseudo $\mathrm{R}^{2}$ & 0.094 & 0.095 & 0.082 & 0.081 \\
\hline
\end{tabular}


Results for the control variables are in line with the prior literature. Of particular interest are the results obtained in the $O_{-} U_{p}$ regressions for Big and LagBig: the former is negative and significant, while the latter is positive and significant. These results indicate that after a firm switch the probability of upgrading the opinion is significantly lower (higher) if the new (salient) firm is a big one. This confirms the finding in prior research that switching from a big to a nonbig firm is used as a particular opinion-shopping strategy (e.g., Chan et al. 2006; DeFond et al. 2000; Gómez-Aguilar and Ruiz-Barbadillo 2003). However, it is important to notice that unreported tests show qualitatively the same results when we replicate our analyses in the subsample with only big audit firms (1,829 observations). Successful opinion-shopping at the firm level occurs within the big firms, which audit almost $90 \%$ of our sample.

The results presented in this section are consistent with $\mathrm{H} 1 \mathrm{a}$ and inconsistent with $\mathrm{H} 1 \mathrm{~b}$. As expected, successful opinion-shopping occurs at the firm level but not at the partner level. We turn now our attention to $\mathrm{H} 2 \mathrm{a}$ and $\mathrm{H} 2 \mathrm{~b}$, where we investigate the strategies of companies that use the audit switching decision to get a more favorable opinion.

\section{Prior opinion-shopping attempts and subsequent firm switches}

We argue that companies prefer to opinion-shop at the partner level because it is less costly and more opaque. Therefore, we expect that companies first try to opinion-shop at the partner level and, if that fails, then switch the firm. If that is the case, firm switching would be more likely when prior attempts to opinion shop at the partner level are not successful, and vice versa.

We provide evidence on the relation between the output of prior attempts to opinion-shop at the partner level and subsequent firm switching activity in columns (1) and (2) of Table 9. In particular, we present the results of the probit regressions where firm switching is a function of a 
dummy variable, UnSuccessOpnShopP (or SuccessOpnShopP), that equals 1 when in any of the three previous years there is an unsuccessful (or successful) attempt to shop the opinion at the partner level, and 0 otherwise. The model also includes the set of control variables of model (2) (results of the control variables are omitted for the sake of brevity). In particular, we define unsuccessful partner-level opinion-shopping attempts as cases when:

i. OpnShopP is negative in $t-1$ (suggesting that a partner switch will be favorable), there is a partner switch in $t$ but the company gets a modified opinion; or

ii. OpnShopP is positive in $t-1$ (suggesting that retaining the partner will be favorable), the company actually retains the partner in $t$ but gets a modified opinion.

In turn, successful partner-level opinion-shopping attempts are cases when:

i. OpnShopP is negative in $t-1$ (suggesting that a partner switch will be favorable), there is a partner switch in $t$ and the company actually gets a clean opinion; or

ii. OpnShopP is positive in $t-1$ (suggesting that retaining the partner will be favorable), the company retains the partner in $t$ and gets a clean opinion. ${ }^{1}$

Consistent with hypothesis $\mathrm{H} 2 \mathrm{a}, \mathrm{UnSuccess} O \mathrm{pnShopP}$ is positive and significantly related to the probability of a firm switch, and the coefficient of SuccessOpnShopP is negative, although not statistically significant at conventional levels. These results suggest that companies may attempt to opinion shop first at the partner level, and switch the firm when they are unsuccessful. Alternatively, if companies are not able to entirely influence the partner switchingretention decision, for example because it is the consequence of the rotation policy imposed by

\footnotetext{
${ }^{1}$ Notice that, by construction, using OpnShopP2 leads to exactly the same unsuccessful or successful opinionshopping variables.
} 
the firm, these results are also consistent with opinion-shopping behavior at the firm level being motivated by a partner-level switching policy that does not favor to the company. Even in this scenario, the possibility of losing the client likely motivates firms to consult with the company before imposing a non-preferred audit partner.

Table 9: Opinion-shopping attempts and subsequent firm switching activity.

Columns (1) and (2) show the results of the probit regressions where firm switching is a function of a dummy variable, UnsuccessOpnShopP and SuccessOpnShopP respectively, equaling 1 whether in any of the three prior years the company's opinion-shopping at the partner level was unsuccessful (i.e. if OpnShopP is negative in $t$-1, the company changes the audit partner in $t$ and gets a modified opinion, or if OpnShopP is positive in $t-1$, the company does not change the partner in $t$ and gets a modified opinion) or successful (i.e. if OpnShopP is negative in $t$-1, the company changes the audit partner in $t$ and gets a clean opinion, or if $O p n S h o p P$ is positive in $t$ - 1 , the company does not change the partner in $t$ and gets a clean opinion) respectively, and the rest of the control variables of model (2) (results omitted for the sake of brevity). Columns (3) and (4) show the results of the probit regressions where firm switching is a function of a dummy variable, UnsuccessOpnShopF and SuccessOpnShopF respectively, equaling 1 whether in any of the three prior years the company's opinion-shopping at the firm level was unsuccessful (i.e. if $O p n S h o p F$ is negative in $t-1$, the company changes the audit firm in $t$ and gets a modified opinion, or if OpnShopF is positive in $t$-1, the company does not change the firm in $t$ and gets a modified opinion) or successful (i.e. if $O p n S h o p F$ is negative in $t$-1, the company changes the audit firm in $t$ and gets a clean opinion, or if $O p n S h o p F$ is positive in $t$-1, the company does not change the firm in $t$ and gets a clean opinion) respectively, and the rest of the control variables of model (2) (results omitted for the sake of brevity). Z-statistics, corrected by time series dependence, are reported below the estimated coefficients. Variables definitions are in Appendix II. Statistical significance is indicated by $*$ p-value $<0.1, * *$ p-value $<0.05$, and $* * *$ p-value $<0.01$.

(1) SwitchF $0.503 * * *$

SuccessOpnShopP

UnsuccessOpnShopF

$(2)$ SwitchF

SuccessOpnShopF
(3)

\begin{tabular}{lrrrr} 
Variables & SwitchF & SwitchF & SwitchF & SwitchF \\
\hline UnsuccessOpnShopP & $0.503^{* * *}$ & & & \\
& {$[4.45]$} & & & \\
SuccessOpnShopP & & -0.145 & & \\
UnsuccessOpnShopF & & {$[-1.18]$} & & \\
& & & $0.436^{* * *}$ & \\
SuccessOpnShopF & & & & $-0.345^{* * *}$ \\
& & & & {$[-3.12]$} \\
\hline Other control variables & Yes & Yes & Yes & Yes \\
Year and industry effects & Yes & Yes & Yes & Yes \\
Observations & 1,890 & 1,890 & 1,890 & 1,890 \\
LR $\chi 2$ & $95.01^{* * *}$ & $80.97^{* * *}$ & $97.53^{* * *}$ & $90.28^{* * *}$ \\
Pseudo R & 0.102 & 0.084 & 0.095 & 0.093 \\
\hline
\end{tabular}

Under $\mathrm{H} 2 \mathrm{~b}$ we expect that if a firm switching decision does not favor the company, there is an escalation, whereby the company engages in another firm-level attempt to shop for a more favorable opinion. We provide evidence consistent with this prediction in columns (3) and (4) of 
Table 9, where the probability of firm switching is now expressed as a function of the success of prior firm-level opinion-shopping attempts and other control variables (results for the control variables are omitted for the sake of brevity). Thus, UnsuccessOpnShopF is a dummy variable equaling 1 when in any of the three prior years the company's opinion-shopping at the firm level was unsuccessful (i.e. $O p n S h o p F$ is negative in $t$-1, the company switches the audit firm in $t$ and gets a modified opinion; or OpnShopF is positive in $t-1$, the company does not change the firm in $t$ and gets a modified opinion), and 0 otherwise. Similarly, SuccessOpnShopF is a dummy variable equaling 1 when in any of the three prior years the company's firm-level opinionshopping was successful (i.e. OpnShop $F$ is negative in $t$-1, the company switches the audit firm in $t$ and gets a clean opinion; or OpnShopF is positive in $t-1$, the company does not change the firm in $t$ and gets a clean opinion), and 0 otherwise. Again, the results confirm our expectations, since unsuccessful (successful) firm-level opinion-shopping attempts are positively (negatively) and significantly related to the probability of a subsequent firm switch. Untabulated results reveal that Unsuccess OpnShopF is not significantly related to the probability of a subsequent partner switch, which supports our argument that an unsuccessful attempt at the firm level is not followed by an attempt at the partner level since it is unlikely that the company looks for a more lenient partner within the new firm.

The results presented in this section support our predictions in hypotheses $\mathrm{H} 2 \mathrm{a}$ and $\mathrm{H} 2 \mathrm{~b}$, suggesting that opinion shoppers prefer switching the partner than the firm; and that when they fail to secure the desired opinion, companies implement increasingly aggressive attempts to get a more favorable opinion. 


\section{THE EFFECT OF REGULATION ON OPINION-SHOPPING}

Following the calls by Lennox (2000) and DeFond and Zang (2014), in this section we further exploit our setting to study whether changes in audit regulation affect opinion-shopping activity. Specifically, the passage of the Financial Law in 2002 introduced changes that potentially generated a shock to the companies' and auditors' incentives to incur in opinion-shopping: (1) mandatory partner rotation (every seven years); and (2) lower audit partner solidarity within firms, which refers to the drop of the direct and joint liability of all partners within the firm previously established by the Audit Law of 1988. Since 2002 only the signing partner and the firm are liable in case of an audit failure (Biedma López 2012). We argue that these regulatory changes increased the opportunities to opinion-shop at the partner level; and given the clients' preference to switch partners, this could also reduce the firm-level opinion-shopping activity.

\section{Voluntary partner switches versus mandatory partner rotations}

We argue that the regulatory changes introduced by the 2002 Law increased the opportunities to opinion-shop at the partner level for two reasons. First, because the probability that the company influences in the partner switching decision is higher under mandatory rotation. When the partner change becomes mandatory, audit firms must provide their clients with an adequate substitute of the incumbent partner, allowing clients to find more pliable auditors by pressuring the firm to designate the candidate that better fits their preferences (DeFond and Zhang 2014: 310). Second, because limiting the partners' personal responsibility within the firm reduces their incentives to monitor one another.

To test whether partner-level opinion-shopping is more likely under mandatory rotation, we take advantage of the 74 mandatory partner rotation cases that are not considered in our main 
tests (see Table 1), and we carry on three set of tests. First, we estimate the first step of the Lennox approach (equation 1) at the partner level in the sample where we drop the voluntary partner switches and include the mandatory partner rotations. The variable SwitchVar is now SwitchPMAN, a dummy that equals 1 when there is a mandatory partner rotation, and 0 otherwise. Thus, we calculate the estimated probabilities of a modified opinion conditioned to the company having to rotate its partner or not. The means of those probabilities are reported in Panel A of Table 10. When the prior year report is modified (413 observations), we observe the same pattern as the one observed for firm switching in Table 5, and the opposite to that observed for voluntary partner switches: the average predicted probability of a modified opinion is significantly lower if the partner rotates (38.1 percent versus 64.2 percent in the case of partner retention). Additionally, when prior reports are clean (1,454 observations), companies also receive modified reports with lower probabilities if their partner has to rotate. These results indicate that opinion-shopping companies would always choose their partner to rotate, and provide preliminary evidence of opinion-shopping activity related to mandatory partner rotations. $^{2}$

Second, we compare the change in the auditor's opinion before and after mandatory partner rotations ( 74 cases) with the same evidence for voluntary partner switches (258 cases). This is presented in Panel B of Table 10. We observe an economically important increase in the opinion upgrading rate in the mandatory partner rotation group, 9.5 percent versus 3.1 percent in the voluntary partner switching group. The difference in proportions is statistically significant

\footnotetext{
${ }^{2}$ When we repeat the analyses reported in Table 6 (untabulated), the corresponding opinion-shopping variable is not significantly related to the probability of a mandatory partner rotation.
} 
while the proportion of opinion downgrades is not significantly different between the two groups.

Finally, we replicate the probit regression analysis presented in models (2) and (4) of Table 8 including the mandatory partner switching category. Panel $\mathrm{C}$ of Table 10 reports the results (control variables are omitted for the sake of brevity). In columns (1) and (3) SwitchP equals 1 when there is a voluntary partner switch, and 0 otherwise; while SwitchPMAN equals 1 when there is a mandatory partner rotation, and 0 otherwise. Therefore, the reference is the group where no partner switch occurs. In the $O P_{-} U p$ model (column 1), the coefficient of SwitchP is negative and statistically significant while the coefficient of SwitchPMAN is not significant. Therefore, voluntary partner switching is associated with a significantly lower probability of opinion upgrading than no partner switching while that is not the case when the partner rotation is mandatory. In the $\mathrm{OP}_{-}$Down model any of the two variables is significant, as expected. It seems that the mandatory rotation rule reduced the fresh eyes effect associated with partner switching. Indeed, when we estimate the same model in the sample containing only partner changes, either voluntary or mandatory (columns 2 and 4), the variable SwitchPMAN is positive and significant in the $O P \_U p$ model, meaning that mandatory partner rotations are associated with a significantly higher probability of opinion upgrading than voluntary partner switches.

Overall, the results reported in Table 10 indicate that mandatory rotation fosters partnerlevel opinion-shopping. An interpretation for these findings is that the new regulation created a certain turn on how partners rotate clients within the firms, forcing rotations which may not be in the best interest of the quality of the audit. 
Table 10: Evidence on mandatory partner rotation versus voluntary partner switches.

Panel A column (1) shows the mean predicted probabilities of getting a modified opinion in year $t$ if the opinion in year $t$ - 1 is modified conditioned to mandatory partner rotation. The $t$-statistics of the $t$-tests which null is that the two means are equal appears below. Panel A column (2) shows the same for the group of observations where the opinion in $t-1$ is clean. Panel B shows the proportion of companies where the opinion from year $t-1$ to year $t$ is upgraded (column 1), or downgraded (column 2 ) in the voluntary and mandatory partner switching groups, together with the proportion tests where the null hypothesis is that the proportions are equal in the two groups. Panel C shows the results of the probit regressions of $O P_{-} U p$ and $O P_{-}$Down on partner switching variables and other controls. SwitchP equals 1 whether there is a voluntary partner switch, and 0 otherwise; and SwitchPMAN equals 1 whether there is a mandatory partner rotation, and 0 otherwise. Variables definitions are in Appendix II. Statistical significance is indicated by $*$ for $\mathrm{p}$-value $<0.10 ; * *$ for $\mathrm{p}$-value $<0.05$; and $* * *$ for $\mathrm{p}$-value $<0.01$.

Panel A: Mean predicted probabilities of modified opinions conditioned to mandatory rotation occurrence

\begin{tabular}{lrr}
\hline & $(1)$ & $(2)$ \\
& Lag_OP=1 $(\mathrm{N}=413)$ & Lag_OP $=0(\mathrm{~N}=1,454)$ \\
\cline { 2 - 3 } Mean $\operatorname{Prob}(\widehat{O P}=1 \mid$ SwitchMAN $=1)$ & $38.1 \%$ & $6.6 \%$ \\
Mean $\operatorname{Prob}(\widehat{O P}=1 \mid$ SwitchMAN $=0)$ & $64.2 \%$ & $8.3 \%$ \\
\hline Diff test $(t$-statistic $)$ & $-24.02 * * *$ & $-5.76^{* * *}$ \\
\hline
\end{tabular}

Panel B: Mandatory versuss voluntary partner switches and changes in opinion. Univariate tests

\begin{tabular}{|c|c|c|c|c|}
\hline \multirow{2}{*}{\multicolumn{3}{|c|}{ Partner switches }} & \multicolumn{2}{|c|}{ Change in the auditor's opinion } \\
\hline & & & $O P=0 \& \operatorname{Lag} O P=1$ & $O P=1 \& \operatorname{Lag} O P=0$ \\
\hline \multirow[t]{2}{*}{ Voluntary switches } & $\mathrm{N}$ & 258 & 8 & 18 \\
\hline & $\%$ & & $3.1 \%$ & $7.0 \%$ \\
\hline \multirow[t]{2}{*}{ Mandatory rotations } & $\mathrm{N}$ & 74 & 7 & $\begin{array}{r}7 \\
050\end{array}$ \\
\hline & $\%$ & & $9.5 \%$ & $9.5 \%$ \\
\hline \multicolumn{3}{|c|}{ Difference in proportions (z-statistic) } & $-2.32 * *$ & -0.71 \\
\hline
\end{tabular}

Panel C: Mandatory versus voluntary partner switches and changes in opinion. Regression analysis

\begin{tabular}{lrrrr}
\hline & $(1)$ & $(2)$ & $(3)$ & $(4)$ \\
Variables & $O P \_U p$ & $O P_{-} U p$ & $O P_{-}$Down & OP_Down \\
\hline SwitchP & $-0.371^{* *}$ & - & 0.029 & - \\
& {$[-2.32]$} & - & {$[0.22]$} & - \\
SwitchPMAN & 0.309 & $1.007^{* *}$ & 0.332 & 0.359 \\
& {$[1.21]$} & {$[2.17]$} & {$[1.29]$} & {$[1.02]$} \\
\hline Year effects & Yes & No & Yes & No \\
Industry effects & Yes & No & Yes & No \\
Observations & 2,125 & 332 & 2,125 & 332 \\
LR $\chi 2$ & $141.71^{* * *}$ & $18.73^{*}$ & $102.58^{* * *}$ & 13.30 \\
Pseudo R & 0.087 & 0.154 & 0.077 & 0.077 \\
\hline
\end{tabular}




\section{Firm-level opinion shopping under a mandatory partner rotation regime}

Given that prior results reveal a clients' preference to switch the partner rather than the firm, the higher opportunities to opinion-shop at the partner level after the Financial Law of 2002 could also result in lower opinion-shopping activity at the firm level. To test this, we extend models (2) and (3) by including two additional regressors: an indicator variable $M A N$ which equals 1 for the period 2003-2014, and 0 otherwise; and its interaction with the firm level opinion-shopping variable in model (2) (OpnShop $F^{*} M A N$ or $\left.O p n S h o p F 2 * M A N\right)$, and with the firm switching variable in model (3) (Switch $\left.F^{*} M A N\right)$. A positive coefficient of the interaction terms in the estimation of these extended models would be consistent with the thesis that after the 2002 regulation firm-level opinion-shopping is less pervasive.

Results of these estimations are reported in Table 11. As discussed by Ai and Norton (2003), unlike in linear models, interaction effects in non-linear models differ across observations, with a positive interaction effect being possible for some observations and a negative for others. Thus, we use the procedure suggested by Norton, Wang and Ai. (2004) to obtain the correct coefficients and $z$-statistics of the interaction effects for each observation, and we report the means. The results show that the coefficients of the interactions are positive, but they are not statistically significant in any case. Therefore, we conclude that firm-level opinionshopping activity did not significantly change after 2002 . The greater opportunities to opinionshop at the partner level were not enough to significantly constrain opinion-shopping activity at the firm level. This evidence confirms our expectation that in the analyzed setting within-firm quality is more homogenous than across-firm quality, leading to greater opportunities for identifying lenient auditors by changing firms rather than partners. 


\section{Table 11: Regulatory changes and firm level opinion-shopping activity.}

Columns (1) and (2) show the results of the probit regressions of firm switching (SwitchP) on the opinion-shopping variables, its interaction with $M A N$ (which equals 1 for the mandatory partner rotation period (2003-2014), and 0 otherwise) and all the additional controls included in models reported in Table 6. Column (3) shows the results of the probit regressions of $O P_{-} U p$ on the firm switching variable (SwitchF), its interaction with $M A N$ and all the additional controls included in models reported in Table 9. Only coefficients and $z$-statistics of the variables of interest are reported. Z-statistics, corrected by time series dependence, are reported below the estimated coefficients. For the interactions we report the mean coefficient and z-statistic obtained from the Norton et al. (2004) procedure. Statistical significance is indicated by $*$ p-value $<0.1, * *$ p-value $<0.05$, and $* * * p$-value $<0.01$. Variables definitions are in Appendix II.

\begin{tabular}{lccc}
\hline Variables & $(1)$ & $(2)$ & $(3)$ \\
MAN & SwitchF & SwitchF & $O P \_U p$ \\
OpnShopF & -0.247 & -0.254 & 0.208 \\
& {$[-0.75]$} & {$[-0.76]$} & {$[0.60]$} \\
OpnShopF*MAN & $-1.734^{* * *}$ & & \\
& {$[-2.63]$} & & \\
OpnShopF2 & 0.146 & & \\
& {$[1.14]$} & $-0.806^{* * *}$ & \\
OpnShopF ${ }^{*} M A N$ & & {$[-3.90]$} & \\
SwitchF & & 0.050 & \\
& & {$[0.99]$} & $0.536^{* *}$ \\
SwitchF*MAN & & $-0.23]$ \\
& & & {$[-0.82]$} \\
\hline Other control variables & & & Yes \\
Observations & Yes & Yes & 2,051 \\
LR $\chi^{2}$ & 2,051 & 2,051 & $142.49^{* * *}$ \\
Pseudo R & $95.90^{* * *}$ & $102.65^{* * *}$ & 0.095 \\
\hline
\end{tabular}

Therefore, the evidence reported in Table 11 indicates that, despite the greater possibilities to opinion-shop at the partner level, opinion-shopping activity at the firm level is not less pervasive under a mandatory partner rotation regime. This is consistent also with Bamber and Bamber (2009) assertion that partner-level effects are of second order as compared to firmlevel effects. 


\section{CONCLUSIONS}

We examine firm-level and partner-level opinion-shopping in the Spanish setting. Using both the Lennox's (2000) approach and the analysis of pre- versus post-switching auditor opinions, we find strong evidence of successful firm-level opinion-shopping. Companies would have received modified reports more often under different voluntary firm switching decisions; and voluntary firm switches positively relate to upgrades of the audit opinion. In contrast, results indicate that voluntary partner switches bring about a fresh eye effect. Companies would have not received modified reports more often under different partner switching decisions. On the contrary, partner switching is negatively related to the probability of opinion upgrading. In all likelihood, our results at the partner level reflect internal partner rotation practices which are effective in improving audit quality. New audit partners are more conservative and less prone to issue a clean report if a colleague modified the report in the previous year.

Our results also reveal that firm switches are associated to unsuccessful prior attempts to opinion shop at the partner level, which is consistent with partner-level switching being preferred by companies, and firm switching being the second choice when partner switches fail to secure the desired opinion. Additionally, unsuccessful opinion-shopping attempts at the firm level relate to a higher probability of a subsequent voluntary firm switch, indicating that companies engage in increasingly aggressive opinion-shopping strategies to get a more favorable opinion.

Finally, we offer evidence on the effects of regulation on opinion-shopping. Overall, the results suggest that the regulatory changes introduced by the Financial Law in 2002, including mandatory partner rotation, did not improve audit quality. We observe that the fresh eyes effect associated with partner switching disappears when partner rotation becomes mandatory. 
Moreover, despite the greater opportunities to opinion-shop at the partner level, firm-level opinion-shopping is still pervasive after such regulatory change.

Our results have implications for regulators. Our research suggests that conclusions from the firm-level research on audit quality may not be extrapolated to the partner level, and that firm and partner level regulations cannot be used as substitutes. In fact, we observe opposite effects of voluntary auditor switches at the firm and partner level. This evidence is important for standard setters in many countries who, oftentimes, justify to regulate at the partner level because of the unconvincing evidence on the firm level effects (e.g., GAO 2003). Additionally, our results at the partner level contrast with those found in the Chinese setting by Chen et al. (2016). The Spanish and the Chinese audit markets share some characteristics, like the weak investors' protection and enforcement mechanisms; but differ in others that determine the opinion-shopping opportunities at the partner level, like the level of concentration and competition amongst partners within the same firm and the incentives for partners to monitor one another. Regulatory bodies should be aware that each audit market has specific characteristics that result in specific problems, which may require (or not) specific regulations.

Finally, it is important to notice that our findings do not allow to conclude about the potential effects of a mandatory rotation rule at the firm level, as established by the recent EC Regulation of 2014, already transposed to the Spanish Audit Law of 2015. We provide evidence that voluntary firm switches are related to opinion-shopping activity. However, it is unclear whether a mandatory firm rotation rule would eliminate, or strengthen, the incentives of firms and/or companies to incur in these practices ( $\mathrm{Lu} 2006)$. 


\section{REFERENCES}

Ai, C. R., and Norton E.C. 2003. Interaction terms in logit and probit models. Economics Letters 80(1), 123-129.

American Institute of Certified Public Accountants (AICPA). 1978. The commission on auditors responsibilities: Report, conclusions and recommendations. New York, NY: AICPA.

American Institute of Certified Public Accountants (AICPA). 1992. Statement of position regarding mandatory rotation of audit firms of publicly held companies. New York, NY: AICPA.

Bamber, E.M., and Bamber, L.S. 2009. Discussion of: Mandatory audit-partner rotation, audit quality and market perception: Evidence from Taiwan. Contemporary Accounting Research 26(2), 393-492.

Bamber, E.M., and Stratton, R.A. 1997. The information content of the uncertainty-modified audit report: Evidence from bank officers. Accounting Horizons 11(2), 1-11.

Beck, P.J, and Wu, M.G.H. 2006. Learnings by doing and audit quality. Contemporary Accounting Research 23(1), 1-30.

Biedma López, E. 2012. El comité de auditoría como salvaguarda de la independencia del auditor. Evidencias empíricas para el caso español. Instituto de Contabilidad y Auditoría de Cuentas: Madrid.

Carey, P., and Simnett, R. 2006. Audit partner tenure and audit quality. The Accounting Review 81(3), 653-687.

Carrera, N., Gómez-Aguilar N., Humphrey C., and Ruiz-Barbadillo E. 2007. Mandatory audit firm rotation in Spain: A policy that was never applied. Accounting, Auditing \& Accountability Journal 20(5), 671-701.

Carson, E., Fargher, N.L., Geiger, M.A., Lennox, C.S., Raghunandan, K., and Willekens, M. 2013. Audit reporting for going-concern uncertainty: A research synthesis. Auditing: A Journal of Practice and Theory 32(1), 353-384.

Chan, H.K., Lin, K.Z., and Mo, P.L. 2006. A political-economic analysis of auditor reporting and auditor switches. Review of Accounting Studies 11(1), 21-48.

Chan, H.K., and Wu, D. 2011. Aggregate quasi rents and auditor independence: Evidence from audit firm mergers in China. Contemporary Accounting Research 28(1), 175-213.

Chen, P.F., He, S., Ma, Z., and Stice, D.E. 2012. Qualified audit opinions and debt contracting. Working paper. Hong Kong University of Science and Technology.

Chi, H-Y., and Chin, C-L. 2011. Firm versus partner measures of auditor industry expertise and effects on audit quality. Auditing: A Journal of Practice and Theory 30(2), 201-229.

Chen, F., Peng, S., Xue, S., Yang Z., and Ye, F. 2016. Do audit clients successfully engage in opinion-shopping? Partner-level evidence. Journal of Accounting Research 54(1), 79-112.

Choi, S.K., and Jeter, D.C. 1992. The effect of modified audit opinion on earnings response coefficients. Journal of Accounting and Economics 14(2-3), 229-247. 
Chow, C.W., and Rice, J. 1982. Modified audit opinions and auditor switching. The Accounting Review 57(2), 326-335.

Christensen, H.B., Hail, L., and Leuz, C. 2013. Mandatory IFRS reporting and changes in enforcement. Journal of Accounting and Economics 56, 147-177.

Citron, D.B., and Taffier, R.J. 1992. The audit report under going concern uncertainties: An empirical analysis. Accounting and Business Research 22(88), 337-345.

Central Intelligence Agency (CIA). (2014). Spain. In The World Factbook. Retrieved from https://www.cia.gov/library/publications/the-world-factbook/geos/sp.html

Craswell, A.T. 1988. The association between modified opinions and auditor switches. Accounting and Business Research 19(73), 23-31.

Davidson, W.N., Jiraporn, P. and DaDalt, P. 2006. Causes and consequences of audit shopping: An analysis of auditor opinions, earnings management and auditor changes. Quarterly Journal of Business and Economics 45(1\&2), 69-87.

DeAngelo, L.E. 1981. Auditor size and audit quality. Journal of Accounting and Economics 3(3), 183-199.

DeFond, M.L., and Subramanyam, K. 1998. Auditor changes and discretionary accruals. Journal of Accounting and Economics 25(1), 35-68.

DeFond, M.L., Wong, T.J., and Li, S. 2000. The impact of improved auditor independence on audit market concentration in China. Journal of Accounting and Economics 28(3), 269-305.

DeFond, M.L., Raghunandan, K., and Subramanyam, K. 2002. Do non-audit services fees impair auditor independence? Evidence from going concern opinions. Journal of Accounting Research 40(4), 1247-1274.

DeFond, M.L., and Zhang, J. 2014. A review of archival auditing research. Journal of Accounting and Economics 58 (2-3): 275-32.

Dhaliwal, D.S., Lamoreaux, P.T., Lennox, C.S., and Mauler, L.M. 2014. Management influence on auditor selection and subsequent impairments of auditor independence during the post-SOX period. Contemporary Accounting Research 32(2), 575-607.

Dye, R. 1991. Informational motivated auditor replacement. Journal of Accounting and Economics 14(4), 347-374.

Eichenseher, J., Hagigi, M., and Shields, D. 1989. Market reaction to auditor changes by OTC companies. Auditing: A Journal of Practice and Theory 9(1), 29-40.

European Commission (EC). 2006. Directive 2006/43/EC of the European Parliament and of the Council of 17 May 2006 on statutory audits of annual accounts and consolidated accounts, amending Council Directives 78/660/EEC and 83/349/EEC and repealing Council Directive 84/253/EEC. Brussels: Official Journal of the European Union L157/87.

European Commission (EC). 2010. Green Paper. Audit policy: Lessons from the crisis. Brusels, October 13.

European Commission (EC). 2014a. Regulation No 537/2014 of the European Parliament and of the Council of 16 April 2014 on specific requirements regarding statutory audit of public- 
interest entities and repealing Commission Decision 2005/909/EC. Official Journal of the European Union, 27.05.2014, L 158/77.

European Commission (EC). 2014b. Directive 2014/56/EC of the European Parliament and of the Council of 16 April 2014 amending Directive 2006/43/EC on statutory audits of annual accounts and consolidated accounts. Official Journal of the European Union 27.05.2014, L 158/196. Firth, M. 1980. A note on the impact of audit qualifications on lending and credit decisions. Journal of Banking and Finance 4(3), 258-267.

Fried, D., and Schiff, A. 1981. CPA switches and associated market reactions. The Accounting Review 63(4), 663-682.

General Accounting Office (GAO). 2003. Public accounting firms: Required study on the potential effects of mandatory audit firm rotation. Washington, D.C.: General Accounting Office Report GAO-04-216.

García-Benau, M. A., Ruiz Barbadillo, E., Humphrey, C., and Husaini, W. 1999. Success in failure? Reflections on the changing Spanish audit environment. The European Accounting Review 8(4), 701-730.

García Osma, B., A. Gisbert, and E. Heras. 2016. Public oversight systems for statutory auditors in the European Union. European Journal of Law and Economics, forthcoming.

General Accounting Office (GAO). 2004. Report to the senate committee on banking, housing, and urban affairs and the house committee on financial services: Mandatory audit firm rotation study: study questionnaires, responses, and summary of respondents' comments. General Accounting Office, Washington, DC.

Ghosh, A., and Moon. D. 2005. Auditor tenure and perceptions of audit quality. The Accounting Review 80: 585-612.

Gómez-Aguilar, N., and Ruiz-Barbadillo E. 2003. Do Spanish firms change auditor to avoid a modified report? International Journal of Auditing 7, 37-53.

Gow, I., Ormazabal, G., and Taylor, D. 2010. Correcting for cross-sectional and time-series dependence in accounting research. The Accounting Review 85(2), 483-512.

Gul, F.A. 1987. The effects of uncertainty reporting on lending officers' perceptions of risk and additional information required. Abacus 23, 172-181.

Gul, F.A., Wu, D., and Yang, Z. 2013. Do individual auditors affect audit quality? Evidence from archival data. The Accounting Review 88, 1993-2020.

Hsieh, Y.T. and Lin, C.J. 2015. Audit firms' client acceptance decisions: Does partner-level industry expertise matter? (September 23, 2015). Available at SSRN: .

Instituto de Censores Jurados de Cuentas de España (ICJCE) 2014. Informe Anual 2014 (Annual Report 2014). Madrid: ICJCE. Available online at: http://www.icjce.es/adjuntos/informe_anual_2014.pdf.

Johnson, V., Khurana, I., and Reynolds, J. 2002. Audit-firm tenure and the quality of financial reports. Contemporary Accounting Research 25: 637-660.

Kausar, A., Taffler, R., and Tan, C. 2009. The going-concern market anomaly, Journal of Accounting Research 47(1), 213-239. 
Kim, Y., and Park, M. 2006. Auditor changes and the pricing of seasoned equity offers. Accounting Horizons 20(4), 333-349.

Krishnan, J. 1994. Auditor switching and conservatism. The Accounting Review 69(1), 200-215.

Krishnan, J., and Stephens, R.G. 1995. Evidence on opinion-shopping from audit opinion conservatism. Journal of Accounting and Public Policy 14, 179-201.

La Porta, R., Lopez-de-Silanes, F., Shleifer, A., and Vishny, R.W. 2000. Agency problems and dividend policies around the world. The Journal of Finance 55(1), 1-33.

Law 19/1988, of 12 July, on Auditing.

Law 2/1995, of 23 March, on Limited Responsibility Corporations.

Law 44/2002, of 22 November, on Measures to Reform the Financial System.

Law 12/2010, of 30 June, by which it is modified the Law 19/1988 on Auditing.

Law 22/2015, of 20 July, on Auditing.

Lennox, C.S. 1998. Audit quality and auditor switching: Some lessons for policy makers. Available at SSRN: http://ssrn.com/abstract=121048 or http://dx.doi.org/10.2139/ssrn.121048.

Lennox, C.S. 2000. Do companies successfully engage in opinion-shopping? Evidence from the UK. Journal of Accounting and Economics 29, 321-337.

Lennox, C.S. 2003. Opinion-shopping and the role of audit committees when audit firms are dismissed: The US experience. The Institute of Chartered Accountants of Scotland. Bell and Bain Ltd, Glasgow, UK.

Levin, J., and Tadelis, S.. 2005. Profit sharing and the role of professional partnerships. The Quarterly Journal of Economics 120(1), 131-171.

Le Vourc'h, J., and Morand, P. 2011. Study on the effects of the implementation of the acquis on statutory audits of annual and consolidated accounts including the consequences on the audit market. Final report. November 2011. Available at: http://ec.europa.eu/internal_market/auditing/docs/studies/201111-summary_en.pdf.

Lu, T. 2006. Does opinion-shopping impair auditor independence and audit quality? Journal of Accounting Research 44(3), 561-583.

Matsumura, E., Subramanyam, K., and Tucker R. 1997. Strategic auditor behaviour and going concern decisions. Journal of Business Finance and Accounting 24(6), 727-758.

Myers, J., Myers, L., and Omer, T. 2003. Exploring the term of the auditor-client relationship and the quality of earnings: A case for mandatory auditor rotation? The Accounting Review 78: 779-799.

Navas, J.A. 2015. Telefónica pone en marcha el 'contrato del siglo' para buscar nuevo auditor en 2017. El Confidencial, 4th December. Available online at: http://www.elconfidencial.com/empresas/2015-12-04/telefonica-pone-en-marcha-el-contratodel-siglo-para-buscar-nuevo-auditor-en-2017 1113114/

Newton, N.J., Persellin, J., Wang, D., and Wilkins, M. S. 2016. Internal Control Opinionshopping and Audit Market Competition. The Accounting Review 91(2): 603-623. 
Norton, E.C., Wang, H., and Ai, C. 2004. Computing interaction effects and standard errors in logit and probit models. The Stata Journal 4(2), 154-67.

Public Company Accounting Oversight Board (PCAOB). 2011. Concept release on auditor independence and audit firm rotation. PCAOB Release No. 2011-006.

PCAOB. 2013. Improving the transparency of audits: Proposed amendments to PCAOB auditing standards to provide disclosure in the auditor's report of certain participants in the audit. PCAOB Release No. 2013-009.

Ruiz Barbadillo E., Gómez Aguilar, N., and Biedma López, E. 2006. Long-term audit engagements and opinion shopping: Spanish evidence. Accounting Forum 30(1), 61-79.

Ruiz Barbadillo, E., Rodriguez Castro, P., and Biedma López, E. 2016. Entry barriers, concentration and competition in the Spanish audit market. Spanish Journal of Finance and Accounting. Forthcoming.

Securities and Exchange Commission (SEC). 1988. Disclosure amendments to Regulation S-K, Form $8-\mathrm{K}$ and schedule 14A regarding changes in accountants and potential opinion-shopping situations, SEC Financial Reporting Release No.31, Washington, D.C.

Smith, D. 1986. Auditor "subject to" opinions, disclaimers, and auditor changes. Auditing: A Journal of Practice and Theory 15(Supplement), 119-134.

Smith, D., and Nichols, D. 1982. A market test of investor reaction to disagreements. Journal of Accounting and Economics 4(2), 109-120.

Taffler, R., Lu, J., and Kausar, A. 2004. In denial? Stock market under reaction to going-concern audit report disclosures. Journal of Accounting and Economics 38(1-3), 263-296.

Teoh, S.H. 1992. Auditor independence, dismissal threats, and the market reaction to auditor switches. Journal of Accounting Research 30(1), 1-23.

U.S. Senate. 1976. Accounting Establishment: A Staff Study. Report of the Subcommittee on Reports, Accounting, and Management of the Committee on Government Operations (Metcalf Committee Report). U.S. Government Printing Office, Washington, DC. https://archive.org/stream/accstabl00unit/accstabl00unit_djvu.txt.

Vanstraelen, A. 2000. Impact of renewable long-term audit mandates on audit quality. European Accounting Review 9(3), 419-442. 


\section{APPENDIX I: THE SPANISH AUDIT MARKET OF LISTED COMPANIES}

\section{Audit firm market}

The Spanish audit firm market of listed companies is highly concentrated. Small and medium audit firms like Audihispana, BDO Auditores, Grant Thorton, Mazars or Moore Stephens, face high barriers to entry. In our sample, we identify 65 individual firms, although the big firms concentrate almost $90 \%$ of the sample. The big firms present in our sample are: Arthur Andersen (AA), Deloitte \& Touch (DT), Ernst \& Young (EY), PriceWatherhouse (Pw), Coopers \& Lybrand (CL) and KPMG. Table A1 below provides a summary of the evolution of the market share of the audit firms for the sample period, 1995-2014.

Except for years 2002 and 2003, which are not representative since our research design led to drop many observations of these years, the share of non big firms is between 9 and 11 percent every year between 1995 and 2014. However, the market share of each big firm changes considerably over time. Before 2002, the market leader was AA that constantly gained market share since 1995, and audited almost half of the market before its demise in 2002. After 2004 the high competition between the remaining four big firms is reflected in the constant loss of share by DT. This firm acquired the AA's offices and had a market share higher than 45 percent in 2004, ten points higher than in 2014 (34.9 percent). The other three big firms gained market share between 2004 and 2014, especially EY. This evidence is consistent with the decrease in the level of market concentration for listed companies in Spain between 2004 and 2009 reported in Le Vourc'h and Morand (2011) (see their tables 48 and 49, pages 116-120).

\section{Audit partner market}

There are 253 partners in our sample, 212 of which belong to one of the big firms. The majority of the partners audit a minority of the sample and vice versa: 73 percent of the partners (184 out of the 253) audit less than 10 company-year observations, totaling 40 percent of the sample; while 27 percent of the sample partners (69 partners) audit more than 10 company-years and concentrate 60 percent of the sample. Thus, competition in the market for audit partners if low.

The audit partner market is also characterized by high specialization. As shown in Table A2, we identify 136 partners in our sample that audit six or more company-year observations, 32 percent of which audit companies belonging to just one industry while only 14 partners (10 percent) audit companies in four industries. Any audit partner audits companies in more than four industries. Untabulated descriptive statistics indicate that those partners with clients in more than one industry always concentrate the majority of their work in just one industry. 
Table A1. Evolution of the market share of big and non-big firms in the Spanish market of listed companies.

This table shows the evolution of the market share per audit firm in our sample. AA is Arthur Andersen; DT is Deloitte \& Touche, EY is Ernst \& Young; Pw is PriceWaterhouse; and PwC is PriceWaterhouse Coopers.

\begin{tabular}{rrrrrrrrr}
\hline \multirow{2}{*}{ Year } & \multicolumn{7}{c}{ Big firms } & \multirow{2}{*}{ Non-big firms } \\
\cline { 2 - 7 } 1995 & $37.5 \%$ & $7.7 \%$ & $4.8 \%$ & $13.5 \%$ & $14.4 \%$ & $2.9 \%$ & $9.6 \%$ & $9.6 \%$ \\
1996 & $38.5 \%$ & $7.4 \%$ & $7.4 \%$ & $12.3 \%$ & $11.5 \%$ & $4.1 \%$ & $8.2 \%$ & $10.7 \%$ \\
1997 & $40.6 \%$ & $7.8 \%$ & $7.0 \%$ & $11.7 \%$ & $10.2 \%$ & $3.1 \%$ & $10.2 \%$ & $9.4 \%$ \\
1998 & $43.4 \%$ & $6.2 \%$ & $5.4 \%$ & $12.4 \%$ & $9.3 \%$ & $3.1 \%$ & $10.9 \%$ & $9.3 \%$ \\
1999 & $48.2 \%$ & - & $7.0 \%$ & $10.5 \%$ & $10.5 \%$ & - & $14.0 \%$ & $9.6 \%$ \\
2000 & $48.7 \%$ & - & $6.7 \%$ & $9.2 \%$ & $9.2 \%$ & - & $17.6 \%$ & $8.4 \%$ \\
2001 & $46.8 \%$ & - & $4.8 \%$ & $10.3 \%$ & $8.7 \%$ & - & $20.6 \%$ & $8.7 \%$ \\
2002 & - & - & $8.7 \%$ & $14.5 \%$ & $20.3 \%$ & - & $39.1 \%$ & $17.4 \%$ \\
2003 & - & - & $6.3 \%$ & $18.8 \%$ & $18.8 \%$ & - & $35.4 \%$ & $20.8 \%$ \\
2004 & - & - & $45.3 \%$ & $9.4 \%$ & $13.7 \%$ & - & $21.4 \%$ & $10.3 \%$ \\
2005 & - & - & $44.0 \%$ & $12.1 \%$ & $16.4 \%$ & - & $19.0 \%$ & $8.6 \%$ \\
2006 & - & - & $44.1 \%$ & $11.7 \%$ & $13.5 \%$ & - & $19.8 \%$ & $10.8 \%$ \\
2007 & - & - & $43.3 \%$ & $12.5 \%$ & $13.5 \%$ & - & $20.2 \%$ & $10.6 \%$ \\
2008 & - & - & $43.7 \%$ & $13.6 \%$ & $10.7 \%$ & - & $21.4 \%$ & $10.7 \%$ \\
2009 & - & - & $46.0 \%$ & $12.0 \%$ & $11.0 \%$ & - & $22.0 \%$ & $9.0 \%$ \\
2010 & - & - & $43.5 \%$ & $13.0 \%$ & $12.0 \%$ & - & $22.8 \%$ & $8.7 \%$ \\
2011 & - & - & $38.9 \%$ & $13.3 \%$ & $13.3 \%$ & - & $26.7 \%$ & $7.8 \%$ \\
2012 & - & - & $39.6 \%$ & $14.3 \%$ & $11.0 \%$ & - & $24.2 \%$ & $11.0 \%$ \\
2013 & - & - & $36.3 \%$ & $13.2 \%$ & $14.3 \%$ & - & $25.3 \%$ & $11.0 \%$ \\
2014 & - & - & $34.9 \%$ & $17.4 \%$ & $15.1 \%$ & - & $23.3 \%$ & $9.3 \%$ \\
\hline
\end{tabular}


Table A2. Number of partners auditing companies in different industries.

This table reports the distribution of the partners in our sample that audit at least six company-year observations by the number of industries to which each partner's clients belong.

\begin{tabular}{rrr}
\hline Number of industries & Number of partners & $\%$ \\
\hline 1 & 43 & $32 \%$ \\
2 & 52 & $38 \%$ \\
3 & 27 & $20 \%$ \\
4 & 14 & $10 \%$ \\
\hline
\end{tabular}




\section{APPENDIX II: VARIABLES DEFINITION}

\begin{tabular}{|c|c|}
\hline ArInv & Accounts receivable plus inventory over total assets. \\
\hline Big & Dummy equaling 1 when the audit firm is a big international firm, 0 otherwise. \\
\hline$C R$ & Current ratio, calculated as current assets over current liabilities. \\
\hline Growth & Annual sales growth rate. \\
\hline $\operatorname{Lag} X$ & Represents the one year lagged value of the corresponding variable $X$. \\
\hline Leverage & $\begin{array}{l}\text { Total debt over total assets. In the case of outliers (i.e. firms in technical } \\
\text { bankruptcy, where total debt is greater than total assets), we set this ratio to } 1 .\end{array}$ \\
\hline istAge & Number of years since the company's equity is listed. \\
\hline Loss & Dummy equaling 1 when the company has an operating loss, 0 otherwise. \\
\hline$M A N$ & $\begin{array}{l}\text { Dummy equaling } 1 \text { for years after 2002, when the mandatory partner rotation rule } \\
\text { was not in force, } 0 \text { otherwise. }\end{array}$ \\
\hline$O P$ & Dummy equaling 1 when there is a modified opinion, 0 otherwise. \\
\hline$O P_{-} U p$ & $\begin{array}{l}\text { Dummy equaling } 1 \text { when there is an upgrading in the opinion, i.e. } O P=0 \text { and } \\
\operatorname{Lag} O P=1,0 \text { otherwise. }\end{array}$ \\
\hline OP_Down & $\begin{array}{l}\text { Dummy equaling } 1 \text { when there is a downgrading in the opinion, i.e. } O P=1 \text { and } \\
\text { LagOP }=0,0 \text { otherwise. } \\
\text { Dummy equaling } 1 \text { when the audit partner is an expert in the company's industry, }\end{array}$ \\
\hline Pexper & $\begin{array}{l}0 \text { otherwise. A partner is considered to be an expert if he/she is the audit partner } \\
\text { with the largest proportion of assets audited within the company's industry. }\end{array}$ \\
\hline Roa & Return on assets, calculated as net income over total assets. \\
\hline SwitchP & $\begin{array}{l}\text { Dummy equaling } 1 \text { when there is a voluntary partner switch (i.e. a within firm } \\
\text { partner voluntary switch), } 0 \text { otherwise. }\end{array}$ \\
\hline SwitchPMAN & $\begin{array}{l}\text { Dummy equaling } 1 \text { when there is mandatory partner rotation (i.e. a within firm } \\
\text { partner switch after } 2002 \text { where the salient partner tenure is } 7 \text { years or more), } 0 \\
\text { otherwise. }\end{array}$ \\
\hline SwitchF & Dummy equaling 1 when there is an audit firm switch, 0 otherwise. \\
\hline Sales & Total sales. \\
\hline Size & Logarithm of total sales. \\
\hline TenureP & Audit partner tenure with the company up to $t-1$, in number of years. \\
\hline TenureF & Audit firm tenure with the company up to $t-1$, in number of years. \\
\hline$\Delta x$ & Represents the annual change in the corresponding variable $X$. \\
\hline
\end{tabular}




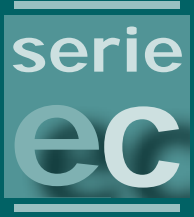

\section{I vie}

Guardia Civil, 22 - Esc. 2, 1 음

46020 Valencia - Spain

Phone: +34 963190050

Fax: +34 963190055

Website: http:/ / www.ivie.es

E-mail: publicaciones@ivie.es 